(1) Nordic Council of Ministers

ANALYSIS OF

PFASs AND TOF

IN PRODUCTS 



\section{Analysis of PFASs and TOF in products}

Daniel Borg, Jenny Ivarsson

TemaNord 2017:543 


\section{Analysis of PFASs and TOF in products}

Daniel Borg, Jenny Ivarsson

ISBN 978-92-893-5067-9 (PRINT)

ISBN 978-92-893-5068-6 (PDF)

ISBN 978-92-893-5069-3 (EPUB)

http://dx.doi.org/10.6027/

TemaNord 2017:543

ISSN $0908-6692$

Standard: PDF/UA-1

ISO 14289-1

(c) Nordic Council of Ministers 2017

Although the Nordic Council of Ministers funded this publication, the contents do not necessarily reflect its views, policies or recommendations.

\section{Nordic co-operation}

Nordic co-operation is one of the world's most extensive forms of regional collaboration, involving Denmark, Finland, Iceland, Norway, Sweden, the Faroe Islands, Greenland, and Åland.

Nordic co-operation has firm traditions in politics, the economy, and culture. It plays an important role in European and international collaboration, and aims at creating a strong Nordic community in a strong Europe.

Nordic co-operation seeks to safeguard Nordic and regional interests and principles in the global community. Shared Nordic values help the region solidify its position as one of the world's most innovative and competitive. 


\section{Contents}

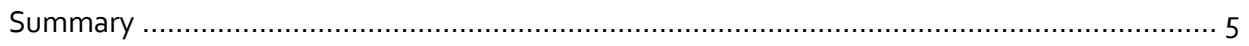

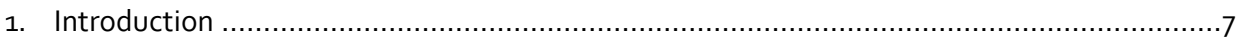

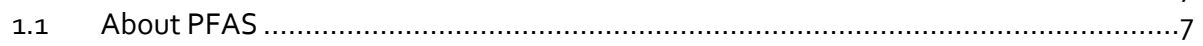

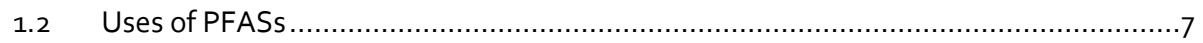

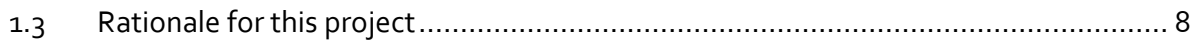

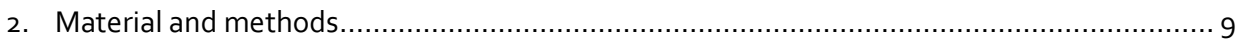

2.1 Analysis of products collected in 2016 for targeted PFAS and TOF........................ 9

2.2 Re-analysis of products collected in 2014 for TOF ............................................10

2.3 Analysis of textiles collected in 2015 for targeted PFASs and TOF........................10

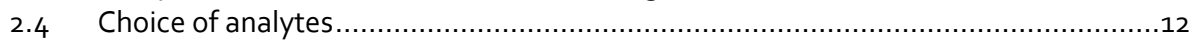

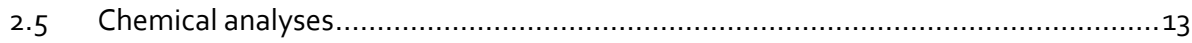

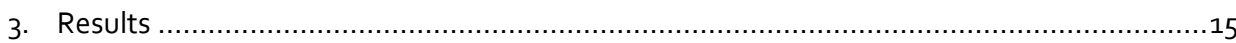

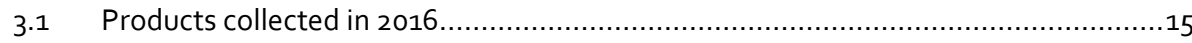

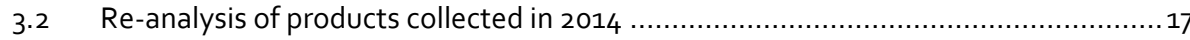

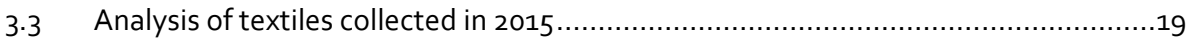

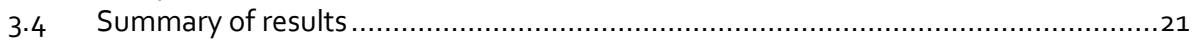

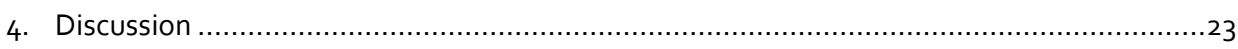

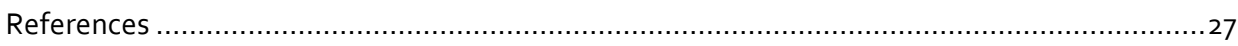

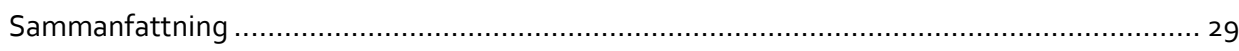

Annex 1. Abbreviations and detection limits ............................................................

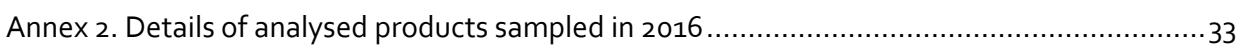

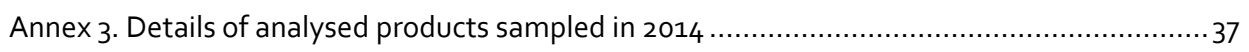

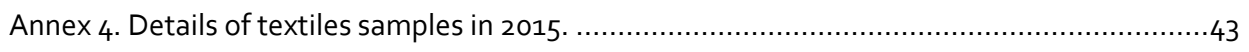





\section{Summary}

Per- and polyfluorinated substances (PFASs) make up a large group of man-made highly fluorinated substances that have been used in industrial and consumer applications for more than six decades. For the last twenty years PFASs have received increasing attention from scientists and regulators following their detection in wildlife and humans globally. It is today recognized that some PFASs are extremely persistent, bioaccumulative and toxic. There are thousands of PFASs on the global market and for many of these there is little information publicly available regarding their potential to affect human health and the environment.

This study is a follow-up of a NORAP (Nordic Risk Assessment Project) project from 2015 where 29 samples of different household products were analysed for 22 PFASs. The result of that study showed that all 29 products contained PFASs and that 12 of the 22 PFASs that were analysed for were detected. Here we have further analysed the products from the study in 2015 together with additional analysis of product types known to contain PFASs or suspected to contain PFASs. Since the targeted PFASs analysis of individual PFAS likely will not display the total PFASs-content of the products, we have analysed them for their total organic fluorine (TOF) content. The results of the TOF-analyses can be used to demonstrate to what extent the PFASs in the targeted analyses comprise the total organic fluorine content and thus provide an estimate of our knowledge about the use of PFASs in the products.

In total 17 new product samples collected in 2016 were in this project analysed for 19 individual PFASs as well as TOF. In addition, 27 samples from the 2015-project were re-analysed for TOF and eight textile samples collected in 2015 for a monitoring project by the Swedish Chemicals Agency were analysed for 22 individual PFASs as well as TOF.

The result of the targeted PFAS analyses of products collected in 2016 showed that PFASs is widely used in these products. PFASs were detected in 16 of the 17 products. All of these contained perfluorooctanoic acid (PFOA) which was the most frequently detected PFAS. Perfluorinated carboxylic acids (PFCA) was the most commonly detected subgroup. Of the perfluorinated sulfonic acids (PFSAs) only perfluorooctane sulfonate (PFOS) was detected, present in one sample. Among the fluorotelomer alcohols (FTOHs) only 6:2 FTOH was found. No fluorotelomer acrylates (FTAs), perfluorooctane sulphonamides (FOSAs) or perfluorooctane sulfonamidoethanols (FOSEs) were detected. Overall, the levels of PFCAs and PFSAs were in the low $\mu \mathrm{g} / \mathrm{m}^{2}$ and $\mu \mathrm{g} / \mathrm{l}$ range in the products and the levels of $6: 2 \mathrm{FTOH}$ were in the $\mu \mathrm{g} / \mathrm{m}^{2}$ range in food packaging and $\mathrm{mg} / \mathrm{l}$ range in waterproofing products and one polish.

The result of the targeted PFAS analysis of textiles collected in 2015 showed that 6 out of 8 products contained PFASs. The most commonly detected PFAS was PFBA. Overall the levels of PFCAs were in the low $\mu \mathrm{g} / \mathrm{m}^{2}$ range and the level of $6: 2 \mathrm{FTOH}$ in the $\mathrm{mg} / \mathrm{m}^{2}$ range. No sample contained PFSAs, FTAs, FTSs, FOSAs or FOSEs. 
The TOF analysis suffered some methodological problems. The method originally developed for TOF-analysis of paper and packaging experienced problems with the analysis of waterproofing treatment sprays and waxes. The TOF-concentrations in the successfully analysed samples spanned over several orders of magnitude for the products collected 2014, 2015 and 2016, respectively, from $\mu \mathrm{g} / \mathrm{m}^{2}$ to $\mathrm{g} / \mathrm{m}^{2}, \mu \mathrm{g} / \mathrm{l}$ to $\mathrm{mg} / \mathrm{l}$, and $\mu \mathrm{g} / \mathrm{kg}$ to $\mathrm{g} / \mathrm{kg}$. The products containing highest concentration of TOF were dental floss $(310 \mathrm{~g} / \mathrm{kg})$, non-stick baking ware $\left(1.7 \mathrm{~g} / \mathrm{m}^{2}\right)$ and table cloth $\left(0.9 \mathrm{~g} / \mathrm{m}^{2}\right)$. The comparisons between the sums of detected PFASs to the TOF concentrations showed that for most samples the analysed PFAS constituted only a very minor part of the TOF (below or far below 1\%). Some samples had TOF concentrations below the limit of detection, of which some did not detect PFASs in the targeted analyses, indicating that these products may be free of PFASs.

This study, important for the understanding of sources for human and environmental exposure to PFASs via consumer products, show that PFASs are widely used in all analysed product types. The large gap between the TOF and the sum of all targeted PFAS analysed illustrate large data gaps on which PFASs that are being used. Further, there is a need for improved TOF-analysis and a follow-up of the study after the implementation of the PFOA restriction would be valuable. 


\section{Introduction}

\subsection{About PFAS}

Per- and polyfluorinated substances (PFASs) make up a large group of man-made highly fluorinated substances that have been used in industrial and consumer applications for more than six decades. For the last twenty years they have received increasing attention from scientists and regulators following their detection in wildlife and human blood globally, even in remote locations far from where they are being used. Initially, most attention was given to perfluorooctane sulfonate (PFOS) and perfluorooctanoate (PFOA), two PFASs commonly detected in humans and biota and also the most studied with regard to toxicity and ecotoxicity. Subsequently more attention has been given to other PFASs.

It is today recognized that some PFASs are extremely persistent with potential for long-range transport, e.g. perfluorinated carboxylic acids (PFCA) and perfluorinated sulfonic acids (PFSA). Some PFASs are also bioaccumulative and toxic. Commonly observed toxic effects in animal studies following PFASs exposure include liver toxicity, decreased body weight, effects on lipid metabolism and thyroid hormone levels, immunotoxicity, carcinogenicity and reproductive toxicity (DeWitt, 2015). Studies in human populations have shown associations between serum concentrations of different PFASs and e.g. serum lipid levels, thyroid disease, certain types of cancers, birth weight and immune response following vaccination (ATSDR, 2015). However, for many PFASs there is little knowledge and publicly available information regarding their potential to affect human health and the environment.

A large number of human biomonitoring studies have shown the presence of different PFASs in human blood globally (DeWitt, 2015). The most significant route of human exposure may differ for different PFAS. For highly bioaccumulative PFASs, such as PFOS, dietary intake of e.g. fish may be constitute the major exposure route whereas for less bioaccumulative PFASs, such as perfluorohexanoic acid (PFHxA), inhalation of indoor dust may be the most significant route of exposure (Vestergren et al., 2012) and where consumer products likely make up a major source.

\subsection{Uses of PFASs}

PFASs are used in many different articles and chemical products due to their properties such as being water-, grease-, and dirt-repellent, temperature resistant and filmforming. There are today a large number of PFASs in use. It has been estimated that more than 3,000 PFAS are available on the global market (Swedish Chemicals Agency, 2015). Known areas of use include as surface active agents, as synthesis chemicals of 
fluoropolymers, in electronic and printing products, in fire-fighting foams, in impregnation of paper, textiles and leather and in pharmaceuticals, plant protection products and biocides (Swedish Chemicals Agency, 2015). Less well-known areas of use include in cosmetics, dental restorative materials, medical equipment and as dirtrepellent agents for building materials, smart phones and solar cells. Information acquired from a previous study on PFASs in consumer products showed that PFASs are widely used in e.g. food contact materials, impregnation sprays, polishes and waxes (Blom and Hanssen, 2015). However, for many PFASs there is limited qualitative and quantitative information on their use (Swedish Chemicals Agency, 2015). Approximately half of the estimated $>3,000$ PFAS on the market lacked information on their use. One reason is that since these substances are highly effective, only low concentrations are needed in products and their usage volumes are relatively low, which results in low associated data requirements within REACH.

Due to regulatory and voluntary actions in recent years there has been a shift from long-chain to short-chain PFASs as well as perfluorinated ethers and polyethers. The reduction in the use of long-chain PFASs has therefore led to an increase in the use of their replacements. The use of PFASs in the EU currently involves mainly PFASs with six perfluorinated carbons (Swedish Chemicals Agency, 2015). Many of these are precursors of e.g. PFCA and PFSA to which they have the ability to degrade and for many there is inadequate information about their toxicity and environmental fate.

\subsection{Rationale for this project}

In 2015 a NORAP project analysed 29 samples of household products for 22 different PFASs (Blom and Hanssen, 2015). The result showed that all products contained PFASs and that 12 out of the 22 of the PFASs that were analysed for were detected.

This project is a follow-up to the 2015 study where we further analyse products of types known to contain PFASs from the previous study in 2015 supplemented with additional analysis of product types suspected to contain PFASs. However, since the targeted PFASs analysis likely will not display the total PFASs-content of the products they were also analysed for their total organic fluorine (TOF) content. The results of the TOF-analyses can be used to demonstrate to what extent the PFAS in targeted PFAS analyses comprise the TOF content and thus provide an estimate of our knowledge about the use of PFASs in the products. In total 17 new products samples were in this project analysed for 19 individual PFASs as well as TOF. In addition, 27 samples from the 2015-project were re-analysed for TOF and eight textile samples collected in 2015 were analysed for 22 individual PFASs and TOF.

This project is important for the understanding of sources for human and environmental exposure to PFASs via consumer products. 


\section{Material and methods}

\subsection{Analysis of products collected in 2016 for targeted PFAS and TOF}

\subsubsection{Selection of samples}

The choice of consumer product types in this study was based on the outcome of the study from Blom and Hanssen (2015) where PFASs were found in e.g. ski waxes, paper and board food packaging and non-stick coating products. In addition, a few additional product types were included. In total 17 products were randomly selected from shelves in a number of Swedish retail stores and supermarkets for analysis. See Table 1 for a list of the analysed products. For a more detailed description of the products, see Annex 3 .

Table 1: Articles collected in 2016 for analysis of targeted PFASs and total organic fluorine (TOF)

\begin{tabular}{|c|c|c|c|c|}
\hline $\begin{array}{l}\text { Sample } \\
\text { ID }\end{array}$ & Product & Brand & Product name & Tested \\
\hline 1 & Cupcake forms & Toppits & Bakformar & Inside of form \\
\hline 2 & Microwave popcorn bag & OLW & Popcorn, smörsmak & Inside of paper package \\
\hline 3 & Microwave popcorn bag & Garant & Mikro Pop, saltade & Inside of paper package \\
\hline 4 & Microwave popcorn bag & Garant & Mikro Pop, smörsmak & Inside of paper package \\
\hline 5 & Microwave popcorn bag & Garant & Ekologiska Mikropopcorn & Inside of paper package \\
\hline 6 & Rinse Aid & Finish & Finish Shine \& protect & Liquid content \\
\hline 7 & Rinse Aid & Fixa & Spolglans miljömärkt & Liquid content \\
\hline 8 & Waterproofing shoe treatment & Springyard & $\begin{array}{l}\text { Universal Waterproofer Classic } \\
\text { Shoe Care, Protect } 3\end{array}$ & Liquid content \\
\hline 9 & Waterproofing shoe treatment & Fibertec & Blue Guard Footwear & Liquid content \\
\hline 10 & $\begin{array}{l}\text { Waterproofing textile } \\
\text { treatment }\end{array}$ & Fibertec & Blue Guard Textile & Liquid content \\
\hline 11 & $\begin{array}{l}\text { Waterproofing textile } \\
\text { treatment }\end{array}$ & Fibertec & Pro Wash (Bluesign approved) & Liquid content \\
\hline 12 & $\begin{array}{l}\text { Waterproofing textile/leather } \\
\text { treatment }\end{array}$ & Imprenex & Waterproofing Express & Liquid content \\
\hline 13 & Shoe wax & Springyard & Shoe Wax Care o2 & liquid/wax content \\
\hline 14 & Floor polish & Nitor & Golvpolish & Liquid content \\
\hline 15 & Furniture polish & $\mathrm{MP}_{52}$ & Möbelpolish, Møbelpolish & Liquid content \\
\hline 16 & Car wax & Turtle wax & Turtle wax original & liquid/wax content \\
\hline 17 & Car wax & Sonax & Flytande hårdvax & liquid/wax content \\
\hline
\end{tabular}




\subsubsection{Analyses}

The products collected in 2016 were analysed for:

- Perfluorinated carboxylic acids (PFCAs): PFBA, PFHxA, PFOA, PFNA, PFDA.

- Perfluorinated sulfonic acids (PFSAs): PFBS, PFHXS, PFOS.

- Fluorotelomer alcohols (FTOHs): 4:2 FTOH, 6:2 FTOH, 8:2 FTOH, 10:2 FTOH.

- Fluorotelomer acrylates (FTAs): 6:2 FTA, 8:2 FTA, 10:2 FTA.

- Perfluorooctane sulphonamides (FOSAs): MeFOSA, EtFOSA.

- Perfluorooctane sulfonamidoethanols (FOSEs): MeFOSE, EtFOSE.

- Total Organic Fluorine (TOF).

\subsection{Re-analysis of products collected in 2014 for TOF}

\subsubsection{Selection of samples}

In total 29 samples of consumer products were collected in the previous study by Blom and Hanssen (2015, Table 2). For a detailed description of the samples and their selection see Blom and Hanssen (2015).

\subsubsection{Analyses}

These samples have previously been analysed for PFCAs, PFSAs, FTOHs, FTSs and PAPs. They were here re-analysed for only TOF, to be compared with the results from the targeted PFASs-analysis in 2014.

\subsection{Analysis of textiles collected in 2015 for targeted PFASs and TOF}

\subsubsection{Selection of samples}

During the autumn of 2015 , the Swedish Chemicals Agency monitored samples of articles from Swedish companies, which included shoes and jackets, and were analysed for PFOS and PFOA (Swedish Chemicals Agency, 2016). Eight textile samples from that monitoring project were here selected for analysis (Table 3 ). 
Table 2: Products collected in 2014 that was previously analysed for PFASs and now subject to analysis of total organic fluorine (TOF)

\section{Sample Product / Type of product}

Sampl
ID

\begin{tabular}{|c|c|}
\hline 1 & Table cloth 1 \\
\hline 2 & Table cloth 2, Maud Teflonduk \\
\hline 3 & Baking paper 1, Unik \\
\hline 4 & Baking paper 2 \\
\hline 5 & Sandwich paper, Unik \\
\hline 6 & Cupcake forms, Unik \\
\hline $7 \mathrm{~A}$ & Microwave popcorn paper 1 Eldorado (salt) \\
\hline $7 \mathrm{~B}$ & Microwave popcorn paper 2 Maarud (salt) \\
\hline 8 & Car wax/polish 1 Turtle wax \\
\hline 9 & Car wax/polish 2 Autoglym \\
\hline 10 & Dishwasher liquid 1, Sun \\
\hline 11 & Dishwasher liquid 2, Finish \\
\hline 12 & Waterproofing shoe treatment product 1, waterguard \\
\hline 13 & Waterproofing shoe treatment product 2, Kiwi \\
\hline $14 \mathrm{~A}$ and $\mathrm{B}$ & Waterproofing textile treatment product 1, two pack TX \\
\hline 15 & Waterproofing textile treatment product 2 , textile proof \\
\hline 16 & Glider for skis 1, HF7 Violet \\
\hline 17 & Glider for skis 2, VR 55 S+LV/Fiolett \\
\hline 18 & Ski wax 1, LF6 Blue \\
\hline 19 & Lubricant for bicycles, Teflon greasetube \\
\hline 20 & Dental floss 1, Easyslide \\
\hline 21 & Dental floss 2, Colgate, mint \\
\hline 22 & Non-stick baking ware, silicon 1 \\
\hline 23 & Non-stick baking ware $2^{1}$ \\
\hline 24 & Non-stick baking ware, cupcakes 1 \\
\hline 25 & Non-stick baking ware, silicon cupcakes $2^{2}$ \\
\hline 26 & Reusable baking liner 1 \\
\hline 27 & Reusable baking liner 2 \\
\hline
\end{tabular}

Note: $\quad{ }^{1}$ Referred to as Non-stick baking ware, silicon 2, Patisse, in Blom and Hanssen (2015).

${ }^{2}$ Referred to as Non-stick baking ware, cupcakes 2, Patisse, in Blom and Hanssen (2015).

Source: Blom and Hanssen (2015).

Table 3: Textiles collected in 2015 for analysis of targeted PFASs and total organic fluorine (TOF)

\begin{tabular}{|c|c|c|c|c|}
\hline $\begin{array}{l}\text { Sample } \\
\text { ID }\end{array}$ & Product & Brand & Product name & Tested \\
\hline 124 & Childrens jacket & Galvin Green & Richie Rainproof jacket junior & Outer material: bluegreen textile \\
\hline 125 & Jacket & Galvin Green & Robin Windstopper mintgrön & Outer material: bluegreen textile \\
\hline 147 & Jacket & Five seasons & Latitude jacket marine & Outer material: blue textile \\
\hline 150 & Childrens jacket & Peak Performance & $\begin{array}{l}\text { Down jacket, child } \\
\text { JRHELIUMJ }\end{array}$ & Outer material: blue textile \\
\hline 155 & Childrens shoe & DC & $\begin{array}{l}\text { DC Shoe Toddler trace TX } \\
\text { Fuchsia }\end{array}$ & Outer material: pink textile \\
\hline 177 & Shoe & JOBI & JOBI walkingsko herr & $\begin{array}{l}\text { Outer material: grey fabric } \\
\text { (textile) }\end{array}$ \\
\hline 184 & Childrens jacket & Didriksson & Wylie Kid's Jacket & Outer material: blue textile \\
\hline 185 & $\begin{array}{l}\text { Childrens rain } \\
\text { Clothing }\end{array}$ & Didriksson & Makalu Kid's Set & Outer material: red textile \\
\hline
\end{tabular}




\subsubsection{Analyses}

The textiles collected in 2015 were analysed for:

- Perfluorinated carboxylic acids (PFCAs): PFBA, PFHxA, PFOA, PFNA, PFDA.

- $\quad$ Perfluorinated sulfonic acids (PFSAs): PFBS, PFHxS, PFOS.

- Fluorotelomer alcohols (FTOHs): 4:2 FTOH, 6:2 FTOH, 8:2 FTOH, 10:2 FTOH.

- Fluorotelomer acrylates (FTAs): 6:2 FTA, 8:2 FTA, 10:2 FTA.

- Fluorotelomer sulfonates (FTSs): 4:2 FTS, 6:2 FTS, 8:2 FTS.

- Perfluorooctane sulphonamides (FOSAs): MeFOSA, EtFOSA.

- Perfluorooctane sulfonamidoethanols (FOSEs): MeFOSE, EtFOSE.

- Total organic fluorine (TOF).

\subsection{Choice of analytes}

The PFASs to be analysed for in the targeted analysis were selected based on the laboratory's availability of analyses in combination with previous knowledge and experience of PFASs in consumer products, i.e. from the NORAP 2015-study (Blom and Hanssen et al., 2015). Since there has been a shift in the use of long-chain PFASs to short-chain PFASs both of these groups were of interest. Table 4 shows which substances that were included in the analyses.

Table 4: PFASs analysed in the targeted analysis of PFASs in products sampled 2016 and in textiles sampled 2015. Abbreviations are explained in annex 1. Substances in bold are short-chain PFASs

\begin{tabular}{|c|c|c|c|c|c|c|}
\hline $\begin{array}{l}\text { Number } \\
\text { of } \\
\text { carbons }\end{array}$ & $\begin{array}{l}\text { Perfluorinated } \\
\text { carboxylic } \\
\text { acids (PFCAs) }\end{array}$ & $\begin{array}{l}\text { Perfluorinated } \\
\text { sulfonic acids } \\
\text { (PFSAs) }\end{array}$ & $\begin{array}{l}\text { Fluortelomer } \\
\text { alcohols } \\
\text { (FTOHs) }\end{array}$ & $\begin{array}{l}\text { Fluortelomer } \\
\text { sulfonates } \\
\text { (FTSs) }\end{array}$ & $\begin{array}{l}\text { Perfluorinated } \\
\text { sulphonamides } \\
\text { (FOSAs) }\end{array}$ & $\begin{array}{l}\text { Perfluorinated } \\
\text { sulfonamido- } \\
\text { ethanols } \\
\text { (FOSEs) }\end{array}$ \\
\hline$C_{4}$ & $\begin{array}{l}\text { PFBA } \\
\text { CAS: } 375-22-4\end{array}$ & $\begin{array}{l}\text { PFBS } \\
\text { CAS: } 29420- \\
49-3 \\
\text { (potassium } \\
\text { salt) }\end{array}$ & - & - & - & - \\
\hline C6 & $\begin{array}{l}\text { PFHxA } \\
\text { CAS: } 307-24-4\end{array}$ & $\begin{array}{l}\text { PFHxS } \\
\text { CAS: 3871-99-6 } \\
\text { (potassium } \\
\text { salt) }\end{array}$ & $\begin{array}{l}4: 2 \text { FTOH } \\
\text { CAS: } 2043-47-2\end{array}$ & $\begin{array}{l}\text { 4:2 FTS } \\
\text { CAS: } 757124- \\
72-4\end{array}$ & - & - \\
\hline C8 & $\begin{array}{l}\text { PFOA } \\
\text { CAS: } 335-67-1\end{array}$ & $\begin{array}{l}\text { PFOS } \\
\text { CAS: 1763-23-1 } \\
\text { (sodium salt) }\end{array}$ & $\begin{array}{l}\text { 6:2 FTOH } \\
\text { CAS: } 647-42-7\end{array}$ & $\begin{array}{l}6: 2 \text { FTS } \\
\text { CAS: } 29420- \\
49-3\end{array}$ & $\begin{array}{l}\text { MeFOSA } \\
\text { CAS: } 31506-32-8 \\
\text { EtFOSA } \\
\text { CAS: } 4151-50-2\end{array}$ & $\begin{array}{l}\text { MeFOSE } \\
\text { CAS: } 2448-09- \\
7 \\
\text { EtFOSE } \\
\text { CAS; } 1691-99- \\
2\end{array}$ \\
\hline $\mathrm{C}_{9}$ & $\begin{array}{l}\text { PFNA } \\
\text { CAS: } 375^{-95-1}\end{array}$ & - & - & - & - & - \\
\hline $\mathrm{C}_{10}$ & $\begin{array}{l}\text { PFDA } \\
\text { CAS: } 335-76-2\end{array}$ & - & $\begin{array}{l}8: 2 \mathrm{FTOH} \\
\text { CAS: } 678-39-7\end{array}$ & - & - & - \\
\hline
\end{tabular}




\subsection{Chemical analyses}

\subsubsection{Targeted PFAS analysis}

In brief, the sample was homogenized by mixing, stirring, milling and / or cutting with respect to the sample matrix. The sample was spiked by internal isotope-labeled standards for later quantification. The sample was then extracted by ultrasonic extraction of the homogenised sample material with matrix-dependent solvents (multi)-step-sample clean-up. Analysis was done by liquid chromatography coupled with mass spectrometry (LC/MS-MS). (Agilent HPLC 1290 Infinity Serie coupled with Agilent 6460A Triple Quad LC/MS-MSMS). Identification was performed via retention time and molecule or fragment ions. Quantification of the native PFC components was calculated via internal isotope-labeled standards (isotope dilution method).

\subsubsection{Analysis of total organic fluorine (TOF)}

This method has originally been developed for cardboard and paper, as a collaboration between Eurofins and the Ministry of Food, Agriculture and Fisheries of Denmark.

The sample (paper or cardboard) was shredded using a Retsch ultra centrifugal mill ZM 200. After homogenization the fluff was pressed to pellets using a handhold press. The pellets which have a weight of approx. 100 to $120 \mathrm{mg}$ are cut in half to fit the TOX crucible. The two halves were weighed and placed in the crucible.

The combustion was carried out using an Envirotech TOX-100 TOX-oven. About 10 pellets must be processed to sustain a LOQ of $1 \mathrm{mg} / \mathrm{kg}$ fluorine. The combustion gases were absorbed in $10 \mathrm{ml}$ of a buffer solution of $0.0018 \mathrm{~mol} / \mathrm{l} \mathrm{Na} \mathrm{CO}_{3}$ and $0.0020 \mathrm{~mol} / \mathrm{l}$ $\mathrm{NaHCO}_{3}$. All 10 combustions were absorbed by the same solution step by step. The technique is based, in part, on DIN 51723 and EN ISO 10304-1.

The fluoride was measured in the solution using a Methrom 882 compact IC plus (LOQ fluoride $=0.1 \mathrm{mg} / \mathrm{l}$ ). The results were calculated using the sum of the weighed sample and the volume of the absorber solution. In addition blanks were analysed using the same conditions/method. 



\section{Results}

\subsection{Products collected in 2016}

\subsubsection{Analysis of PFCAs and PFSAs}

The result of the targeted PFAS analysis showed that all products contained PFASs, except the furniture polish (sample 15) (Tables 5, 6).

All samples containing PFASs also contained PFOA, which was the most commonly detected PFAS, ranging between $0.03-0.20 \mu \mathrm{g} / \mathrm{m}^{2}$ and $0.23-2.8 \mu \mathrm{g} / \mathrm{l}$, respectively (Table 5). PFBA and PFHxA were frequently detected in approximately half of the samples (9/17), whereas PFDA was less frequent (3/17) and PFNA not detected at all. PFHXA was measured at the highest concentrations of the PFCAs and PFSAs, up to $5.3 \mu \mathrm{g} / \mathrm{L}$ in the floor polish (sample 14). One product, a microwave popcorn bag (sample 2), contained PFOS at a concentration of $0.14 \mu \mathrm{g} / \mathrm{m}^{2}$. No other PFSA was detected in any sample.

\begin{tabular}{|c|c|c|c|c|c|c|c|c|c|}
\hline \multirow{2}{*}{$\begin{array}{l}\text { Sample } \\
\text { ID }\end{array}$} & \multirow[t]{2}{*}{ Article } & \multicolumn{8}{|c|}{ Concentration $\left(\mu \mathrm{g} / \mathrm{m}^{2}\right)$} \\
\hline & & PFBA & PFHxA & PFOA & PFNA & PFDA & PFBS & PFHxS & PFOS \\
\hline 1 & Cupcake forms & 0.05 & $<L O D$ & 0.03 & $<$ LOD & $<L O D$ & $<$ LOD & $<$ LOD & $<$ LOD \\
\hline 2 & Microwave popcorn bag & 0.34 & 0.15 & 0.19 & $<$ LOD & $<L O D$ & $<L O D$ & $<$ LOD & 0.14 \\
\hline 3 & Microwave popcorn bag & 0.35 & $<$ LOD & 0.19 & $<$ LOD & $<$ LOD & $<$ LOD & $<$ LOD & $<$ LOD \\
\hline 4 & Microwave popcorn bag & 0.21 & 0.06 & 0.20 & $<$ LOD & 0.14 & $<$ LOD & $<$ LOD & $<$ LOD \\
\hline 5 & Microwave popcorn bag & 0.43 & 0.65 & 0.13 & $<$ LOD & $<$ LOD & $<$ LOD & $<$ LOD & $<$ LOD \\
\hline 6 & Rinse Aid & $<$ LOD & $<$ LOD & 0.75 & $<$ LOD & $<$ LOD & $<L O D$ & $<$ LOD & $<$ LOD \\
\hline 7 & Rinse Aid & $<$ LOD & $<$ LOD & 0.75 & $<$ LOD & 0.47 & $<$ LOD & $<$ LOD & $<$ LOD \\
\hline 8 & $\begin{array}{l}\text { Waterproofing shoe } \\
\text { treatment }\end{array}$ & $<$ LOD & $<L O D$ & 0.53 & $<$ LOD & $<L O D$ & $<$ LOD & $<$ LOD & $<$ LOD \\
\hline 9 & $\begin{array}{l}\text { Waterproofing shoe } \\
\text { treatment }\end{array}$ & 0.33 & 2.5 & 0.23 & $<$ LOD & $<L O D$ & $<$ LOD & $<$ LOD & $<$ LOD \\
\hline 10 & $\begin{array}{l}\text { Waterproofing textile } \\
\text { treatment }\end{array}$ & 0.80 & 3.6 & 1.4 & $<$ LOD & 0.45 & $<L O D$ & $<$ LOD & $<$ LOD \\
\hline 11 & $\begin{array}{l}\text { Waterproofing textile } \\
\text { treatment }\end{array}$ & 0.78 & 2.3 & 0.48 & $<$ LOD & $<L O D$ & $<L O D$ & $<$ LOD & $<$ LOD \\
\hline 12 & $\begin{array}{l}\text { Waterproofing } \\
\text { textile/leather treatment }\end{array}$ & $<L O D$ & $<L O D$ & 0.49 & $<$ LOD & $<L O D$ & $<L O D$ & $<L O D$ & $<L O D$ \\
\hline 13 & Shoe wax & $<L O D$ & 4.7 & 0.53 & $<$ LOD & $<$ LOD & $<$ LOD & $<L O D$ & $<L O D$ \\
\hline 14 & Floor polish & 0.47 & $5 \cdot 3$ & 0.59 & $<$ LOD & $<L O D$ & $<$ LOD & $<$ LOD & $<$ LOD \\
\hline 15 & Furniture polish & $<L O D$ & $<$ LOD & $<L O D$ & $<$ LOD & $<L O D$ & $<$ LOD & $<L O D$ & $<L O D$ \\
\hline 16 & Car wax & $<$ LOD & 0.54 & 1.4 & $<$ LOD & $<$ LOD & $<$ LOD & $<L O D$ & $<$ LOD \\
\hline 17 & Car wax & $<$ LOD & $<$ LOD & 2.8 & $<$ LOD & $<$ LOD & $<$ LOD & $<$ LOD & $<$ LOD \\
\hline
\end{tabular}




\subsubsection{Analysis of FTOHs and FTAs}

The analysis of FTOHs and FTAs detected only 6:2 FTOH that was present in 5 of the 17 samples (Table 6). The concentrations of 6:2 FTOH were the highest of all the analysed PFAS, $26.7 \mu \mathrm{g} / \mathrm{m}^{2}$ in a microwave popcorn bag (sample 5) and ranging between 1,834$120,300 \mu \mathrm{g} / \mathrm{l}$ in the floor polish (sample 15) and a waterproofing shoe treatment (sample 9), respectively. The highest concentrations overall were found in waterproofing treatment products.

Table 6: Concentrations of FTOHs and FTAs in articles collected in 2016

\begin{tabular}{|c|c|c|c|c|c|c|c|c|}
\hline \multirow{2}{*}{$\begin{array}{l}\text { Sample } \\
\text { ID }\end{array}$} & \multirow[t]{2}{*}{ Article } & \multicolumn{7}{|c|}{ Concentration $\left(\mu \mathrm{g} / \mathrm{m}^{2}\right)$} \\
\hline & & $\begin{array}{r}4: 2 \\
\text { FTOH }\end{array}$ & $\begin{array}{r}6: 2 \\
\text { FTOH }\end{array}$ & $\begin{array}{r}8: 2 \\
\text { FTOH }\end{array}$ & $\begin{array}{r}10: 2 \\
\text { FTOH }\end{array}$ & $\begin{array}{r}6: 2 \\
\text { FTA }\end{array}$ & $\begin{array}{r}8: 2 \\
\text { FTA }\end{array}$ & $\begin{array}{l}\text { 10:2 } \\
\text { FTA }\end{array}$ \\
\hline 1 & Cupcake forms & $<$ LOD & $<L O D$ & $<$ LOD & $<$ LOD & $<L O D$ & $<L O D$ & $<L O D$ \\
\hline 2 & Microwave popcorn bag & $<$ LOD & $<$ LOD & $<$ LOD & $<$ LOD & $<$ LOD & $<$ LOD & $<$ LOD \\
\hline 3 & Microwave popcorn bag & $<$ LOD & $<$ LOD & $<$ LOD & $<$ LOD & $<$ LOD & $<$ LOD & $<$ LOD \\
\hline 4 & Microwave popcorn bag & $<L O D$ & $<$ LOD & $<$ LOD & $<L O D$ & $<$ LOD & $<L O D$ & $<$ LOD \\
\hline 5 & Microwave popcorn bag & $<L O D$ & 26.6 & $<$ LOD & $<$ LOD & $<$ LOD & $<$ LOD & $<$ LOD \\
\hline 6 & Rinse Aid & $<L O D$ & $<$ LOD & $<$ LOD & $<$ LOD & $<$ LOD & $<$ LOD & $<$ LOD \\
\hline 7 & Rinse Aid & $<L O D$ & $<$ LOD & $<$ LOD & $<$ LOD & $<$ LOD & $<$ LOD & $<$ LOD \\
\hline 8 & Waterproofing shoe treatment & $<$ LOD & $<$ LOD & $<$ LOD & $<$ LOD & $<$ LOD & $<$ LOD & $<$ LOD \\
\hline 9 & Waterproofing shoe treatment & $<L O D$ & 120,300 & $<$ LOD & $<$ LOD & $<$ LOD & $<$ LOD & $<$ LOD \\
\hline 10 & Waterproofing textile treatment & $<L O D$ & 43,070 & $<$ LOD & $<$ LOD & $<$ LOD & $<$ LOD & $<L O D$ \\
\hline 11 & Waterproofing textile treatment & $<$ LOD & $<$ LOD & $<$ LOD & $<$ LOD & $<$ LOD & $<$ LOD & $<$ LOD \\
\hline 12 & $\begin{array}{l}\text { Waterproofing textile/leather } \\
\text { treatment }\end{array}$ & $<L O D$ & 12,340 & $<$ LOD & $<L O D$ & $<L O D$ & $<L O D$ & $<L O D$ \\
\hline 13 & Shoe wax & $<L O D$ & $<$ LOD & $<$ LOD & $<L O D$ & $<L O D$ & $<L O D$ & $<$ LOD \\
\hline 14 & Floor polish & $<$ LOD & 1,834 & $<$ LOD & $<$ LOD & $<$ LOD & $<$ LOD & $<$ LOD \\
\hline 15 & Furniture polish & $<$ LOD & $<$ LOD & $<\mathrm{LOD}$ & $<$ LOD & $<$ LOD & $<$ LOD & $<$ LOD \\
\hline 16 & Car wax & $<L O D$ & $<L O D$ & $<$ LOD & $<$ LOD & $<L O D$ & $<$ LOD & $<$ LOD \\
\hline 17 & Car wax & $<L O D$ & $<L O D$ & $<$ LOD & $<L O D$ & $<L O D$ & $<L O D$ & $<L O D$ \\
\hline
\end{tabular}

\subsubsection{Analysis of FOSAs and FOSES}

FOSAs and FOSEs were not detected in any samples (data not shown).

\subsubsection{TOF analysis and comparison to the targeted PFASs analysis}

Analysis of TOF was successful for 10 of 17 samples (Table 7). All food-contact materials were possible to analyse for TOF, however the analyses of waterproofing treatments and waxes suffered from methodological problems. For the successfully analysed samples, 7 out of 10 samples had TOF-concentrations above the detection limit.

The result showed TOF-concentrations in food-contact materials ranging from 470 $\mu \mathrm{g} / \mathrm{m}^{2}$ in the sampled cupcake forms (sample 1 ) to $93,000 \mu \mathrm{g} / \mathrm{m}^{2}$ in a microwave popcorn bag (sample 2) (Table 7). In the liquid samples, the concentrations of TOF ranged from $<1,000$ to $18,500 \mu \mathrm{g} / \mathrm{L}$ in the floor polish (sample 14). 
Comparison of the sum of concentrations of all detected PFASs in samples to their respective TOF-concentrations showed that for most samples only a very small fraction $(<1 \%)$ of the TOF content could be explained by the analysed PFASs. The only sample where the TOF to some extent (10\%) could be explained by the analysed PFASs was the floor polish (sample 14).

Table 7: Sum of concentrations of all detected PFAS in products collected 2016, the total organic fluorine (TOF) content of the samples and a quantitative comparison between these

\begin{tabular}{llrrr} 
Sample ID & Product & \multicolumn{3}{c}{ Concentration $\left(\mu \mathrm{g} / \mathrm{m}^{2}\right)$} \\
& & TOF & [PFAS/TOF (\%) \\
\hline 1 & Cupcake forms & 0.08 & 470 & 0.02 \\
2 & Microwave popcorn bag & 0.81 & 93,000 & 0.001 \\
3 & Microwave popcorn bag & 0.54 & 83,000 & 0.001 \\
4 & Microwave popcorn bag & 0.62 & 91,650 & 0.001 \\
5 & Microwave popcorn bag & 27.8 & 52,750 & 0.05 \\
6 & Rinse Aid & 0.75 & $<1,000$ & $>0.08$ \\
7 & Rinse Aid & 1.2 & 2,000 & 0.06 \\
8 & Waterproofing shoe treatment & 0.53 & N.A. & - \\
9 & Waterproofing shoe treatment & 120,303 & N.A. & - \\
10 & Waterproofing textile treatment & 43,076 & N.A. & - \\
11 & Waterproofing textile treatment & 3.6 & $<1,000$ & $>0.36$ \\
12 & Waterproofing textile/leather treatment & 12,341 & N.A. & - \\
13 & Shoe wax & 5.2 & N.A. & - \\
14 & Floor polish & 1,840 & 18,500 & 10.0 \\
15 & Furniture polish & 0 & $<1,000$ & - \\
16 & Car wax & 2.0 & N.A. & - \\
17 & Car wax & 2.8 & N.A. & - \\
\hline
\end{tabular}

\subsection{Re-analysis of products collected in 2014}

\subsubsection{Targeted analysis of individual PFASs}

The results of the targeted PFAS-analyses showed that 15 out of 22 PFASs that were analysed for were detected in the 28 product samples. For a detailed description of the results, see Blom and Hanssen (2015).

\subsubsection{TOF analysis and comparison with targeted analysis}

The TOF analysis was successfully completed for 19 out of 28 samples (Table 8). Methodological problems were encountered primarily for waterproofing treatments and waxes. For the successfully analysed samples, 17 out of the 19 samples had TOFconcentrations above the detection limit.

The results showed TOF-concentrations in food-contact materials ranging from $50 \mu \mathrm{g} / \mathrm{m}^{2}$ in baking paper (sample 4 ) to $1,700,000 \mu \mathrm{g} / \mathrm{m}^{2}$ in a non-stick baking ware 
(sample 23) (Table 8). Relatively high TOF-concentrations were found in table cloths, up to $933,500 \mu \mathrm{g} / \mathrm{m}^{2}$ (sample 2). The highest TOF-concentrations were detected in the dental floss samples, both at 310,000,000 $\mu \mathrm{g} / \mathrm{kg}$ (samples 20 and 21).

Comparison of the sum of concentrations of all detected PFASs in samples to their respective TOF-concentrations showed that for most samples only a small fraction of the TOF content could be explained by the analysed PFASs. The samples where the TOF could be explained by the analysed PFASs to more than $5 \%$ was one of the popcorn bags (sample $7 \mathrm{~b}$ ) and the baking papers (samples 3 and 4 ) as well as the non-stick cupcake baking ware (sample 24).

Table 8: Sum of concentrations of all detected PFAS in products collected 2014, the total organic fluorine (TOF) content of the samples and a quantitative comparison between these

\begin{tabular}{|c|c|c|c|c|}
\hline \multirow[t]{2}{*}{ Sample ID } & \multirow[t]{2}{*}{ Product } & \multicolumn{3}{|c|}{ Concentration $\left(\mu \mathrm{g} / \mathrm{m}^{2}\right)$} \\
\hline & & ¿PFAS (detected) & TOF & ¿PFAS/TOF (\%) \\
\hline 1 & Table cloth 1 & 10.9 & 246,000 & 0.005 \\
\hline 2 & Table cloth 2 & 512 & 933,500 & 0.06 \\
\hline 3 & Baking paper 1 & 4.9 & 65 & 8.2 \\
\hline 4 & Baking paper 2 & 5.2 & 50 & 11.3 \\
\hline 5 & Sandwich paper & 10.3 & 25,400 & 0.04 \\
\hline 6 & Cupcake forms & 3.2 & 330 & 1.1 \\
\hline $7 a$ & Popcorn paper 1 & 4.5 & 91,100 & 0.005 \\
\hline $7 b$ & Popcorn paper 2 & 91.7 & 578 & $15 \cdot 9$ \\
\hline 8 & Car polish 1 & 3.8 & 3,000 & 0.14 \\
\hline 9 & Car polish 2 & 3.6 & 8,000 & 0.05 \\
\hline 10 & Rinse aid $1^{1}$ & 11.4 & 14,500 & 0.08 \\
\hline 11 & Rinse aid $2^{2}$ & 2.6 & $<1,000$ & 0.3 \\
\hline 12 & Waterproofing product, shoes 1 & 1.3 & N.A. & - \\
\hline 13 & Waterproofing product, shoes 2 & $45 \cdot 5$ & N.A. & - \\
\hline $14 \mathrm{~A} / \mathrm{B}$ & Waterproofing product, textiles 1 & 0.66 & $<1,000$ & 0.10 \\
\hline 15 & Waterproofing product, textiles 2 & 261 & N.A. & - \\
\hline 16 & Glider for skis 1 & 157 & N.A. & - \\
\hline 17 & Glider for skis 1 & 1.2 & N.A. & - \\
\hline 18 & Ski wax & 9.9 & N.A. & - \\
\hline 19 & Lubricant for bicycles & 59.0 & N.A. & - \\
\hline 20 & Dental floss 1 & 3.0 & $310,000,000$ & 0.000001 \\
\hline 21 & Dental floss 2 & $19 \cdot 5$ & $310,000,000$ & 0.000006 \\
\hline 22 & Non-stick silicon baking ware 1 & 73.8 & N.A. & - \\
\hline 23 & Non-stick baking ware $2^{3}$ & 5.9 & $1,700,000$ & 0.0004 \\
\hline 24 & Non-stick cupcake baking ware, 1 & 1.4 & 38,500 & 0.005 \\
\hline 25 & Non-stick silicon cupcake baking ware $2^{4}$ & $83 \cdot 4$ & 2,820 & 3.0 \\
\hline 26 & Reusable baking liner 1 & 24.7 & N.A. & 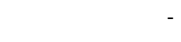 \\
\hline 27 & Reusable baking liner 2 & 172 & 41,150 & 0.4 \\
\hline
\end{tabular}

\footnotetext{
${ }^{1}$ Referred to as Dishwasher liquid 1 in Blom and Hanssen (2015).

2 Referred to as Dishwasher liquid 2 in Blom and Hanssen (2015).

3 Referred to as Non-stick baking ware, silicon 2, Patisse, in Blom and Hanssen (2015).

4 Referred to as Non-stick baking ware, cupcakes 2, Patisse, in Blom and Hanssen (2015).
} 


\subsubsection{Targeted analysis of PFCAs and PFSAs}

The result of the targeted PFAS analysis of samples of textiles collected in 2014 showed that 6 out of 8 products contained PFASs (Tables 9,10 ). The two products that did not contain PFAS (samples 184 and 185) were childrenswear.

The most commonly detected PFAS was perfluorobutanoic acid (PFBA), present in 4 out of 8 products followed by PFHxA and PFOA ( $3 / 8$ products) and perfluorononanoic acid (PFNA)/perfluorodecanoic acid (PFDA) (1 product each). Of the PFCAs, PFOA was detected at the highest concentrations, up to $6.6 \mu \mathrm{g} / \mathrm{kg}$ (sample 125). No sample contained PFSAs.

Table 9: Concentrations of PFCAs and PFSAs in textiles collected in 2015

\begin{tabular}{|c|c|c|c|c|c|c|c|c|c|}
\hline \multirow[t]{2}{*}{ ID } & \multirow[t]{2}{*}{ Product } & \multicolumn{8}{|c|}{ Concentration $(\mu \mathrm{g} / \mathrm{kg})$} \\
\hline & & PFBA & PFHxA & PFOA & PFNA & PFDA & PFBS & PFHxS & PFOS \\
\hline 124 & Richie Rainproof jacket junior & 0.95 & 11.0 & $<$ LOD & $<$ LOD & $<$ LOD & $<$ LOD & $<$ LOD & $<$ LOD \\
\hline 125 & Robin Windstopper & $<$ LOD & 2.6 & 6.6 & 0.45 & 2.7 & $<L O D$ & $<L O D$ & $<L O D$ \\
\hline 147 & Latitude Jacket Marine & 0.38 & 0.33 & 1.7 & $<$ LOD & $<$ LOD & $<$ LOD & $<$ LOD & $<$ LOD \\
\hline 150 & Down jacket, child JRHELIUMJ & $<$ LOD & $<$ LOD & 4.6 & $<L O D$ & $<L O D$ & $<L O D$ & $<$ LOD & $<$ LOD \\
\hline 155 & DC Shoe Toddler trace TX Fuchsia & 0.15 & $<$ LOD & $<$ LOD & $<$ LOD & $<L O D$ & $<$ LOD & $<$ LOD & $<$ LOD \\
\hline 177 & JOBI walkingsko herr & 0.85 & $<$ LOD & $<$ LOD & $<$ LOD & $<$ LOD & $<$ LOD & $<$ LOD & $<$ LOD \\
\hline 184 & Wylie Kid's Jacket & $<$ LOD & $<$ LOD & $<$ LOD & $<$ LOD & $<$ LOD & $<$ LOD & $<$ LOD & $<$ LOD \\
\hline 185 & Makalu Kid's Set & $<$ LOD & $<$ LOD & $<$ LOD & $<$ LOD & $<$ LOD & $<$ LOD & $<$ LOD & $<$ LOD \\
\hline
\end{tabular}

\subsubsection{Targeted analysis of FTOHs and FTAs}

The analysis of FTOHs and FTAs detected only 6:2 FTOH in one samples (Table 10). The concentrations of 6:2 FTOH were the highest of all the analysed PFASs in textiles, 1,405 $\mu \mathrm{g} / \mathrm{kg}$ (sample 124). FTAs or FTSs were not detected in any sample. 
Table 10: Concentrations of FTOHs, FTAs and FTSs in textiles collected in 2015

\begin{tabular}{|c|c|c|c|c|c|c|c|c|c|c|c|}
\hline \multirow[t]{2}{*}{ ID } & \multirow[t]{2}{*}{ Product } & \multicolumn{10}{|c|}{ Concentration $(\mu \mathrm{g} / \mathrm{kg})$} \\
\hline & & $\begin{array}{r}4: 2 \\
\text { FTOH }\end{array}$ & $\begin{array}{r}6: 2 \\
\text { FTOH }\end{array}$ & $\begin{array}{r}8: 2 \\
\text { FTOH }\end{array}$ & $\begin{array}{r}10: 2 \\
\text { FTOH }\end{array}$ & $\begin{array}{r}6: 2 \\
\text { FTA }\end{array}$ & $\begin{array}{r}8: 2 \\
\text { FTA }\end{array}$ & $\begin{array}{l}10: 2 \\
\text { FTA }\end{array}$ & $\begin{array}{r}4: 2 \\
\text { FTS }\end{array}$ & $\begin{array}{r}6: 2 \\
\text { FTS }\end{array}$ & $\begin{array}{r}8: 2 \\
\text { FTS }\end{array}$ \\
\hline 124 & $\begin{array}{l}\text { Richie Rainproof jacket } \\
\text { junior }\end{array}$ & $<$ LOD & 1,405 & $<$ LOD & $<$ LOD & $<L O D$ & $<$ LOD & $<$ LOD & $<L O D$ & $<$ LOD & $<L O D$ \\
\hline 125 & Robin Windstopper & $<L O D$ & $<L O D$ & $<L O D$ & $<L O D$ & $<L O D$ & $<L O D$ & $<L O D$ & $<L O D$ & $<L O D$ & $<L O D$ \\
\hline 147 & Latitude Jacket Marine & $<$ LOD & $<$ LOD & $<$ LOD & $<$ LOD & $<L O D$ & $<$ LOD & $<$ LOD & $<$ LOD & $<$ LOD & $<$ LOD \\
\hline 150 & $\begin{array}{l}\text { Down jacket, child } \\
\text { JRHELIUMJ }\end{array}$ & $<$ LOD & $<L O D$ & $<L O D$ & $<$ LOD & $<L O D$ & $<L O D$ & $<$ LOD & $<$ LOD & $<L O D$ & $<L O D$ \\
\hline 155 & $\begin{array}{l}\text { DC Shoe Toddler trace } \\
\text { TX Fuchsia }\end{array}$ & $<$ LOD & $<$ LOD & $<$ LOD & $<$ LOD & $<L O D$ & $<L O D$ & $<$ LOD & $<L O D$ & $<$ LOD & $<L O D$ \\
\hline 177 & JOBI walkingsko herr & $<$ LOD & $<$ LOD & $<$ LOD & $<$ LOD & $<L O D$ & $<$ LOD & $<$ LOD & $<$ LOD & $<$ LOD & $<$ LOD \\
\hline 184 & Wylie Kid's Jacket & $<$ LOD & $<$ LOD & $<$ LOD & $<$ LOD & $<$ LOD & $<$ LOD & $<$ LOD & $<$ LOD & $<$ LOD & $<$ LOD \\
\hline 185 & Makalu Kid's Set & $<$ LOD & $<$ LOD & $<$ LOD & $<$ LOD & $<$ LOD & $<$ LOD & $<$ LOD & $<$ LOD & $<$ LOD & $<$ LOD \\
\hline
\end{tabular}

\subsubsection{TOF analysis and comparison to the targeted PFASs analysis}

Comparison of the sum of concentrations of all detected PFASs in samples to their respective TOF-concentrations showed that for all samples only a very small fraction $(<1 \%)$ of the TOF content could be explained by the analysed PFASs (table 11$)$. The two samples showing no detected PFASs in the targeted analyses showed TOFconcentrations below the LOD, indicating that the products may be PFAS-free.

Table 11: Sum of concentrations of all detected PFASs in textiles collected 2015, the total organic fluorine (TOF) content of the samples and a quantitative comparison between these

\begin{tabular}{|c|c|c|c|c|}
\hline \multirow[t]{2}{*}{ ID } & \multirow[t]{2}{*}{ Product } & \multicolumn{3}{|c|}{ Concentration $(\mu \mathrm{g} / \mathrm{kg})$} \\
\hline & & ¿PFAS (detected) & TOF & $\Sigma$ ¿PFAS/TOF (\%) \\
\hline 124 & Richie Rainproof jacket junior & 1417.0 & $8,750,000$ & 0.02 \\
\hline 125 & Robin Windstopper & 12.3 & $9,550,000$ & 0.0001 \\
\hline 147 & Latitude Jacket Marine & 2.4 & 81,500 & 0.003 \\
\hline 150 & Down jacket, child JRHELIUMJ & 4.6 & 295,000 & 0.002 \\
\hline 155 & DC Shoe Toddler trace TX Fuchsia & 0.2 & $<1,000$ & 0.02 \\
\hline 177 & JOBI walkingsko herr & 0.9 & 120,000 & 0.0007 \\
\hline 184 & Wylie Kid's Jacket & Not detected & $<1,000$ & - \\
\hline 185 & Makalu Kid's Set & Not detected & $<1,000$ & 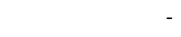 \\
\hline
\end{tabular}




\subsection{Summary of results}

\subsubsection{Targeted PFAS analyses}

The result of the targeted PFAS analysis of products collected in 2016 showed that PFASs are widely used in these products, all products except the furniture polish contained PFASs. All samples that contained PFASs also contained PFOA, which was most commonly detected. PFBA and PFHXA were frequently detected whereas PFDA was less frequent and PFNA not detected at all. Of the PFSAs only PFOS was detected, in one sample. Among the FTOHs only 6:2 FTOH was found. No FTAs, FOSAs or FOSEs were detected. Overall, the levels of PFCAs and PFSAs were in the low $\mu \mathrm{g} / \mathrm{m}^{2}$ and $\mu \mathrm{g} / \mathrm{l}$ range, some close to the limit of detection, and the levels of $6: 2 \mathrm{FTOH}$ in the $\mu \mathrm{g} / \mathrm{m}^{2}$ range in food packaging and $\mathrm{mg} / \mathrm{l}$ range, the highest levels of the analysed PFASs, in waterproofing products and one polish.

The result of the targeted PFAS analysis of textiles collected in 2015 showed that 6 out of 8 products contained PFASs. The most commonly detected PFAS was PFBA followed by PFHxA and PFOA. Overall, the levels of PFCAs were in the low $\mu \mathrm{g} / \mathrm{m}^{2}$ range, some close to the limit of detection, and the level of $6: 2 \mathrm{FTOH}$ in the $\mathrm{mg} / \mathrm{m}^{2}$ range. No sample contained PFSAs, FTAs, FTSs, FOSAs or FOSEs.

\subsubsection{TOF analyses and comparison to the targeted PFASs analyses}

The analysis of TOF suffered from some methodological problems. The method, originally developed for TOF-analysis of paper and packaging, experienced problems with analysis of waterproofing treatment sprays and waxes.

The TOF-concentrations in the successfully analysed samples spanned over several orders of magnitude for the products collected 2014, 2015 and 2016, respectively, from $\mu \mathrm{g} / \mathrm{m}^{2}$ to $\mathrm{g} / \mathrm{m}^{2}, \mu \mathrm{g} / \mathrm{l}$ to $\mathrm{mg} / \mathrm{l}$, and $\mu \mathrm{g} / \mathrm{kg}$ to $\mathrm{g} / \mathrm{kg}$, respectively. The products containing the highest concentration of TOF were dental floss (310 g/ $/ \mathrm{kg})$, non-stick baking ware $\left(1.7 \mathrm{~g} / \mathrm{m}^{2}\right)$ and table cloth $\left(0.9 \mathrm{~g} / \mathrm{m}^{2}\right)$.

The comparisons between the sums of detected PFASs to the TOF concentrations showed that for most samples the analysed PFAS constituted only a very minor part of the TOF. Some samples had TOF concentrations below the limit of detection, of which some did not detect PFASs in the targeted analysis, indicating that these products may be free of PFASs. 



\section{Discussion}

The analyses showed that PFASs are widely used in the sampled products: food-contact materials, waterproofing treatment sprays, waxes, polishes, rinsing aids and textiles.

The most commonly detected PFASs in the samples collected in 2016 were PFOA followed by PFHXA/PFBA (Figure 1). PFOA, which is a long-chain PFAS, was measured in all products that contained PFASs, though there has been a general shift from longchain PFASs to short-chain PFASs (Swedish Chemicals Agency, 2015). A restriction on the use of PFOA and its related substances (i.e. precursors) in products at levels above 1,000 parts per billion (ppb), i.e. 1,000 $\mu \mathrm{g} / \mathrm{kg}$, will be imposed in the EU likely during 2020 (European Commission, 2016). The levels of PFOA as such and its precursor 8:2 FTOH were below 1,000 ppb in all the products included in this report. However, it cannot be excluded that other PFOA-related substances not analysed could be present in the products, given their higher levels of TOF. Thus, a follow-up study after the implementation of the PFOA-restriction in the EU would be of interest in order to review its effect on the use of PFOA. PFOS was detected in one popcorn bag. There is no regulation prohibiting the use of PFOS in food contact materials; however the manufacturer of the popcorn bag does intentionally not add PFOS to their papers which was made of non-recycled fibers (Malmström, personal communication). The level of PFOS was relatively low (1 of 2 samples below LOD) indicating that the presence of PFOS may be due to some kind of background contamination. This manufacturer of microwave popcorn, and likely also other brands, has since the sampling changed to PFAS-free popcorn bag (Malmström, personal communication).

The levels of PFASs in the products varied. Some were close to the limit of detection, indicating that they may represent impurities and/or degradation products of precursors, such as fluorinated polymers, while some were present at higher levels indicating that they are used as functional additives. 6:2 FTOH was found at levels one order of magnitude higher than the PFCAs in waterproofing treatments and one floor polish, showing that this substance constitute a major component in these products. Among the textiles sampled in 2015, PFBA was the most commonly found PFAS, followed by PFHxA and PFOA.

A comparison of the detection frequency of individual PFASs in the products collected in 2014 to the products collected in 2016 indicate a possible decrease in the use of 8:2 FTOH and 6:2 FTOH and an increase in the use of PFOA and PFHXA (Figure 1).

The comparisons between the sums of detected targeted PFASs to the TOF content of the products showed, for the majority of the products, these could only explain a very small proportion of the TOF. One likely explanation is that many of the individual PFASs measured represent degradation products of precursor PFAS, either as stable end-stage products such as the PFCAs and PFSAs, or possible intermediate breakdown products such as the FTOHs. Polymers with fluorinated 
side-chains are commonly used for surface treatments of various materials to make them water-, grease- and dirt-repellent (Swedish Chemicals Agency, 2015). It has been estimated that approximately $80 \%$ of the release of PFCAs to the environment are derived from fluoropolymer manufacture and use (Prevedouros et al., 2006) and that $80 \%$ of fluorotelemers are used in polymers (Ellis et al., 2003). The method for TOF-analysis, that has been developed for paper and packaging, was unfortunately not applicable to liquid impregnation sprays and waxes, due to soot formation, and it was therefore not possible to make a comparison of targeted PFAS to TOF for those. Thus, there is a need for method development to also cover these types of matrices.

Figure 1: Percentage of the 17 products sampled in 2016 with detected PFASs compared to the products sampled in 2014

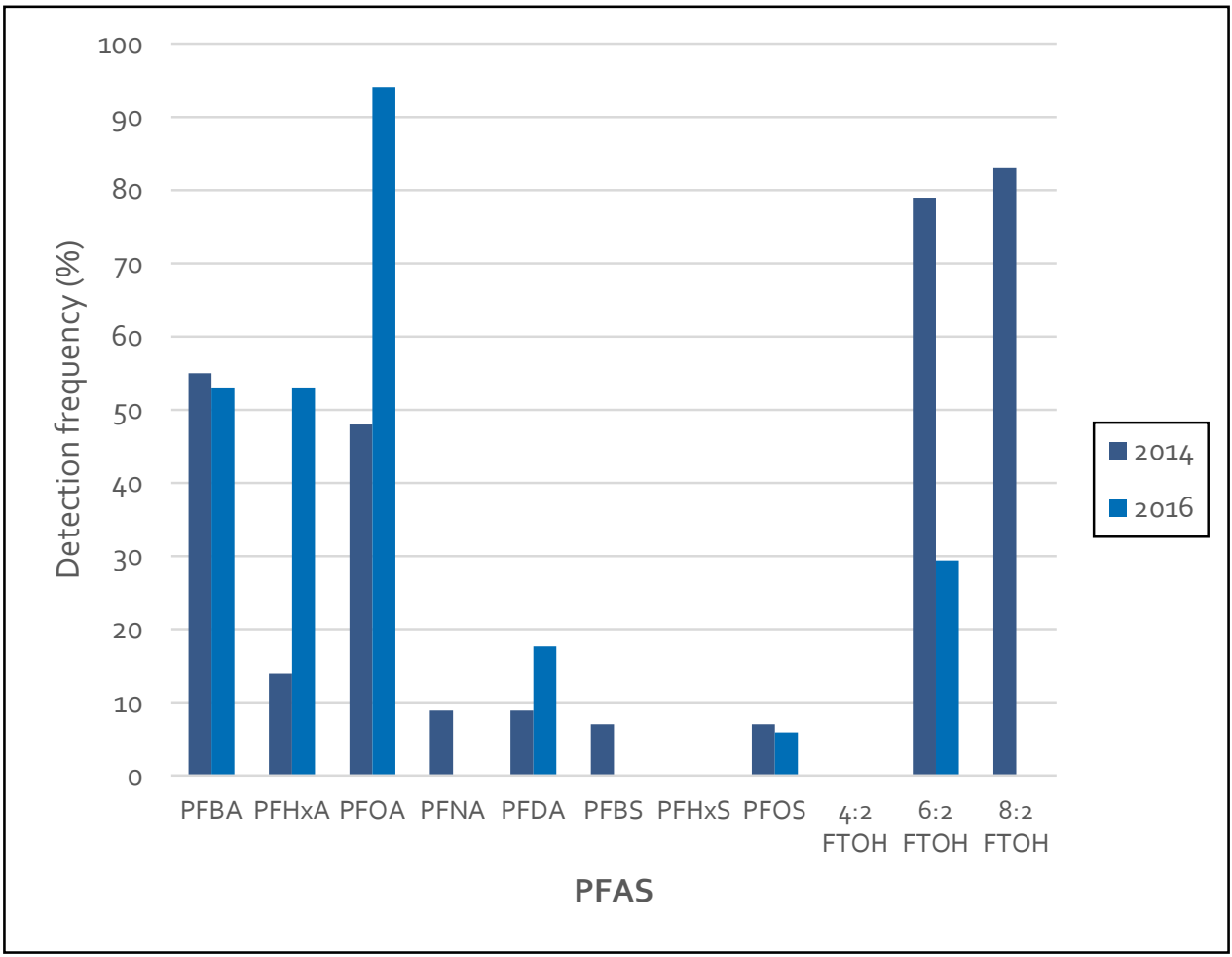

The highest TOF contents, in the $\mathrm{g} / \mathrm{kg}$-range were found in dental floss, one non-stick baking product and in two jackets. The high TOF-contents of the dental floss products can be explained by that they are based on polytetrafluoroethylene (PTFE) (Colgate, 2017; Jordan, 2017). The non-stick baking product is also fluoropolymer-based (Wilson, personal communication) which likely explains the result. For the jackets, it cannot be excluded that a fluoropolymer, such as PTFE, that is commonly used in these products was part of the textile samples. 
In conclusion, the result of this study show that PFASs are widely used in the analysed product types. The large gap between the TOF and the amount of all targeted PFAS that were analysed illustrate the large data gaps on which PFASs that are being used. In addition to the need for better knowledge on which PFASs that are being used there is also a need for improved TOF-analysis of other matrices than the ones that were successfully analysed here. Also, a follow-up of the study after the implementation of the PFOA restriction would be valuable. 



\section{References}

Agency for Toxic Substances and Disease Registry (ATSDR) (2015). Draft toxicological profile for perfluoroalkyls. August 2015.

Blom C and Hanssen L (2015). Analysis of per- and polyfluorinated substances in articles. Nordic Working Papers. ISSN: 2311-0562.

Colgate (2017). http://www.colgateprofessional.co.uk/products/Colgate-total-pro-gum-healthinterdental-floss/overview. Accessed 25.04.2017.

DeWitt (2015). Toxicological effects of perfluoroalkyl and polyfluoroalkyl substances. Humana Press. ISSN 2168-4219. https://doi.org/10.1007/978-3-319-15518-o

Ellis D.A., Martin J.W., Mabury S.A., Hurley M.D., Andersen M.P., and Wallington T.J. (2003): Atmospheric lifetime of fluorotelomer alcohols. Environ Sci Technol 37 (17), 3816-3820. https://doi.org/10.1021/eso34136j

European Commission (2016). Summary of the meeting of the REACH committee. 7-8 December 2016-Brussels.

Jordan (2017). http://www.jordan.no/en/Companies/Orkla-Brands-Nordic/Folder/Jordan/OralCare/Dental-Floss/Easy-Slide-floss. Accessed 25.04.2017.

Prevedouros K, Cousins IT, Buck RC, Korzeniowski SH (2006). Sources, fate and transport of perfluorocarboxylates. Environ Sci Technol. 40:32-44. https://doi.org/10.1021/eso512475

Malmström. Personal communication with Sara Malmström, Orkla Confectionery \& Snacks Sweden, 19.05.2017.

Swedish Chemicals Agency (2015). Occurrence and use of highly fluorinated substances and alternatives. Report 7/15.

Swedish Chemicals Agency (2016). Textil och läder. Tillsyn 3/16. (In Swedish).

Wilson. Personal communication with Campbell Wilson, Whitford Ltd, 17.05.2017. 



\section{Sammanfattning}

Per- och polyfluorerade ämnen (PFAS) utgör en stor grupp av högfluorerade ämnen som har använts inom industrin och i konsumentprodukter i mer än sex årtionden. Under de senaste tjugo åren har PFAS fått ökad uppmärksamhet från forskare och myndigheter efter att de hittats i vilda djur och människor globalt. Det är idag känt att vissa PFAS är extremt svårnedbrytbara, bioackumulerande och giftiga. Det finns tusentals PFAS på den globala marknaden och för många av dessa saknas tillgänglig information om hur de kan påverka människors hälsa och miljön.

Denna studie är en uppföljning av ett projekt från NORAP (Nordic Risk Assessment Project) från 2015 där 29 olika konsumentprodukter analyserades för 22 olika PFAS. Resultatet av den studien visade att alla 29 produkter innehöll PFAS och att 12 av 22 analyserade PFAS kunde detekteras. Här har vi analyserat produkterna från den studien vidare tillsammans med analyser av ytterligare produkter som kan misstänkas innehålla PFAS. Eftersom analyser av enskilda PFAS sannolikt inte kommer att spegla det totala PFAS-innehållet i produkterna har vi analyserat dem också för deras innehåll av totalt organiskt fluor (TOF). Resultaten av TOF-analyserna kan användas för att visa i vilken utsträckning PFAS i de riktade analyserna utgör den totala organiska fluorhalten och därigenom ge en uppskattning av vår kunskap om den totala användningen av PFAS i produkterna.

Sammanlagt 17 nya produktprover som samlats in 2016 analyserades i detta projekt för 19 enskilda PFAS samt TOF. Dessutom analyserades 27 prover från 2015projektet för TOF samt åtta textilprover som samlats in 2015 för ett tillsynsprojekt av Kemikalieinspektionen för 22 individuella PFAS samt TOF.

Resultatet av de riktade PFAS-analyserna av produkter som samlats in 2016 visade att PFAS används i nästan alla av dessa produkter. PFAS fanns i 16 av 17 produkter. Vanligast förekommande var PFOA som hittades i samtliga av dessa produkter. Perfluorerade karboxylsyror (PFCA) var den mest frekevent detekterade PFAS-gruppen. Av de perfluorerade sulfonsyrorna (PFSA) detekterades endast perfluoroktansulfonat (PFOS) som förekom i ett prov. Bland fluorotelomeralkoholerna (FTOH) fanns endast 6 : 2 FTOH. Inga fluorotelomerakrylater (FTA), perfluoroktansulfonamider (FOSA) eller perfluoroktansulfonamidoetanoler (FOSE) detekterades. Sammantaget förekom PFCA och PFSA i låga $\mu \mathrm{g} / \mathrm{m}^{2}$ - och $\mu \mathrm{g} / \mathrm{l}$-nivåer och $6: 2 \mathrm{FTOH}$ i $\mu \mathrm{g} / \mathrm{m}^{2}$-nivåer i livsmedelsförpackningar och mg/l-nivåer i impregneringssprayer och en polish.

Resultatet av den riktade PFAS-analysen av textilier som samlats in 2015 visade att 6 av 8 produkter innehöll PFAS. Den vanligast förekommande var PFBA. Totalt

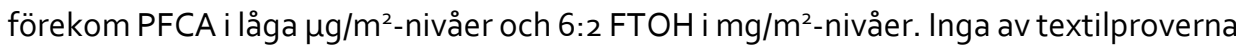
innehöll PFSA, FTA, FTS, FOSA eller FOSE.

TOF-analysen hade en del metodologiska problem. Metoden, som ursprungligen utvecklades för TOF-analys av papper och förpackningar, fungerade inte för 
impregneringssprayer och vaxer. TOF-koncentrationerna i de framgångsrikt analyserade proverna sträckte sig över flera storleksordningar för produkterna som insamlats 2014, 2015 och 2016 - från $\mu \mathrm{g} / \mathrm{m}^{2}$ till g/m², $\mu \mathrm{g} / \mathrm{lill} \mathrm{mg} / \mathrm{l} \mathrm{samt} \mu \mathrm{g} / \mathrm{kg}$ till g/kg. De produkter som innehöll högst koncentrationer av TOF var tandtråd $(310 \mathrm{~g} / \mathrm{kg})$, en non-stick-bakform $\left(1,7 \mathrm{~g} / \mathrm{m}^{2}\right)$ samt en bordsduk $\left(0,9 \mathrm{~g} / \mathrm{m}^{2}\right)$. Jämförelserna mellan summan av koncentrationerna av detekterade PFAS mot TOF visade att för de flesta prover utgjorde de detekterade PFAS endast en mycket liten del av TOF (under eller långt under 1 \%). Några prover hade TOF-koncentrationer under detektionsgränsen, som inte heller visade några PFAS i de riktade analyserna, vilket indikerar att dessa produkter inte innehåller PFAS.

Denna studie är viktig för att förstå källor till människors och miljöns exponering för PFASs via konsumentprodukter. Studien visar att PFAS används utbrett i alla analyserade produkttyper. Den stora skillnaden mellan TOF och summan av detekterade PFAS visar på stora kunskapsluckor gällande vilka PFAS som används. Vidare finns ett behov av en förbättrad TOF-analysmetodik samt en uppföljning av studien efter genomförandet av EUs PFOA-begränsning. 


\section{Annex 1. Abbreviations and detection limits}

Table 1: PFASs abbreviations and internal standards

\begin{tabular}{ll} 
Abbrevation & Full name \\
PFBA & Perfluorobutanoic acid \\
PFCA & Perfluorinated carboxylic acids \\
PFHXA & Perfluorohexanoic acid \\
PFOA & Perfluorooctanoic acid \\
PFNA & Perfluorononanoic acid \\
PFDA & Perfluorodecanoic acid \\
PFBS & Perfluoro butane sulfonic acid \\
PFHXS & Perfluorohexane sulfonic acid \\
PFOS & Perfluorooctane sulfonic acid \\
PFSA & Perfluorinated sulfonic acids \\
FOSA & Perfluorooctane sulfonamide \\
FOSE & Perfluorooctane sulfonamidoethanol \\
4:2 FTS & $4: 2$ Fluorotelomer sulfonic acid \\
$6: 2$ FTS & $6: 2$ Fluorotelomer sulfonic acid \\
8:2 FTS & $8: 2$ Fluorotelomer sulfonic acid \\
4:2 FTOH & $4: 2$ Fluorotelomer alcohol \\
$6: 2$ FTOH & $6: 2$ Fluorotelomer alcohol \\
8:2 FTOH & $8: 2$ Fluorotelomer alcohol \\
10:2 FTOH & $10: 2$ Fluorotelomer alcohol \\
4:2 FTA & $4: 2$ Fluorotelomer acrylate \\
6:2 FTA & $6: 2$ Fluorotelomer acrylate \\
8:2 FTA & $8: 2$ Fluorotelomer acrylate \\
MeFOSA & N-Methyl perfluorooctane sulfonamide \\
EtFOSA & N-Ethyl perfluorooctane sulfonamide \\
MeFOSE & N-Methyl perfluorooctane sulfonamidoethanol \\
EtFOSE & N-Ethyl perfluorooctane sulfonamidoethanol \\
\hline
\end{tabular}





\section{Annex 2. Details of analysed products sampled in 2016}

Table 1: Articles sampled in 2016

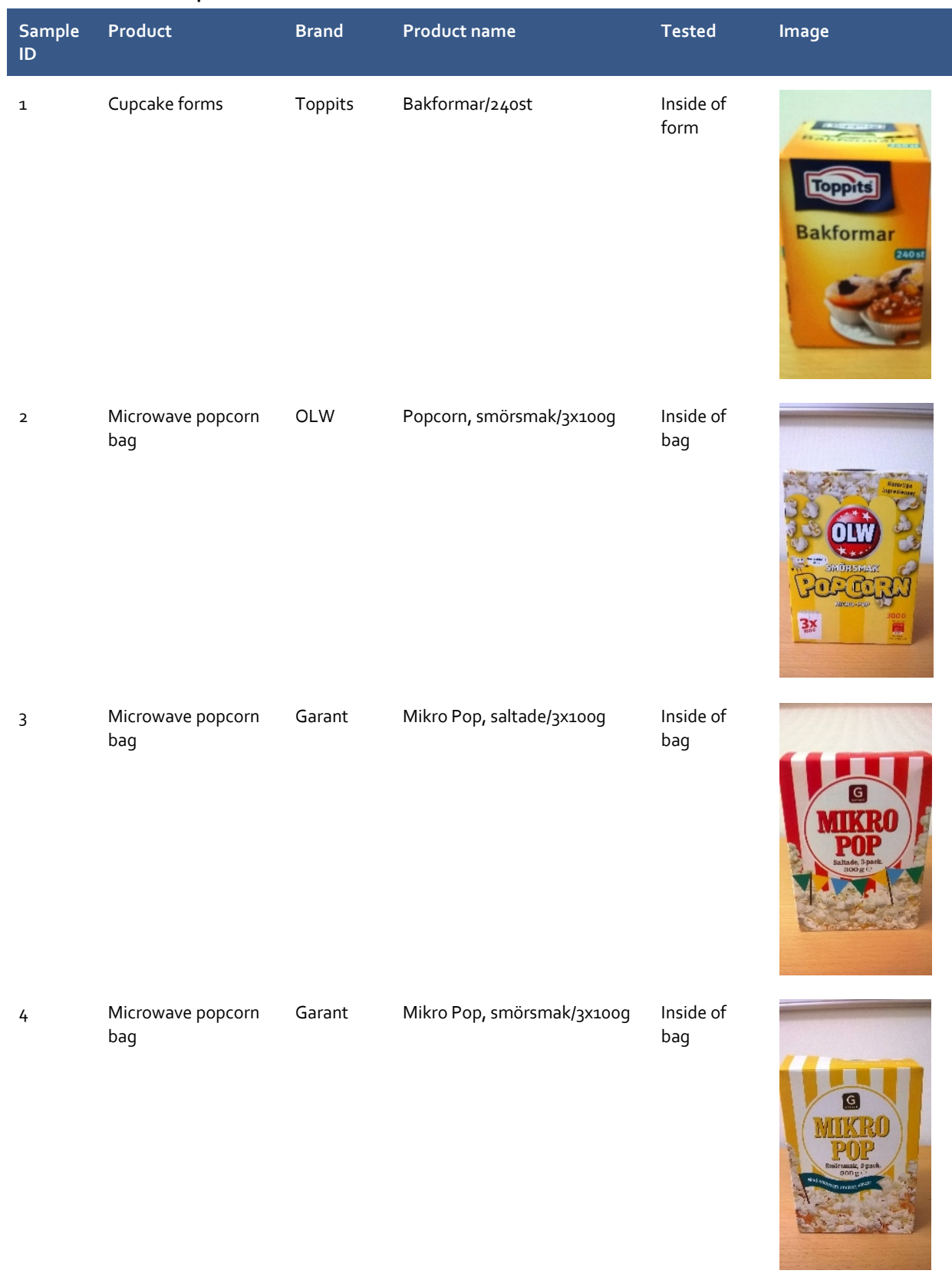




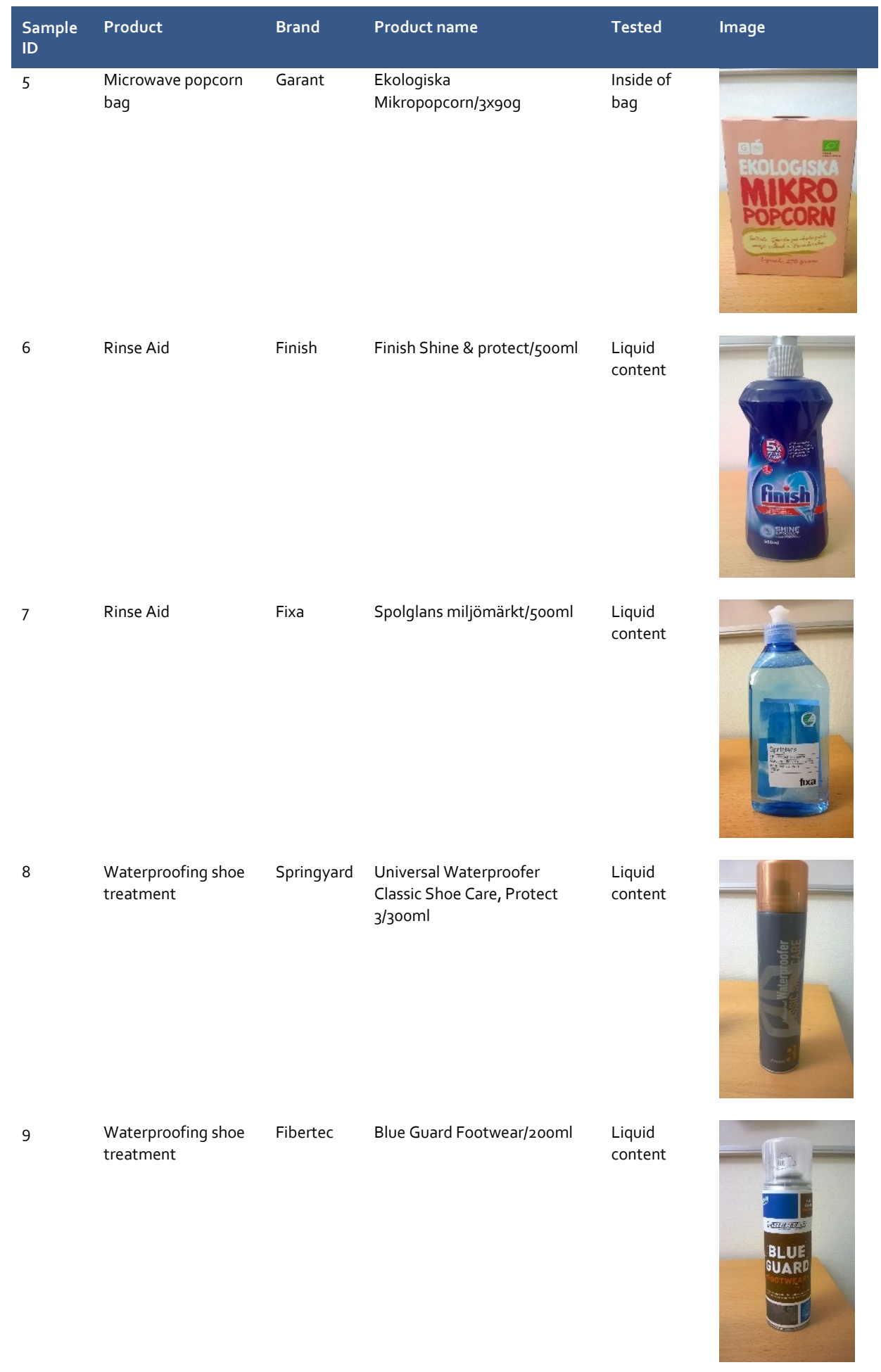




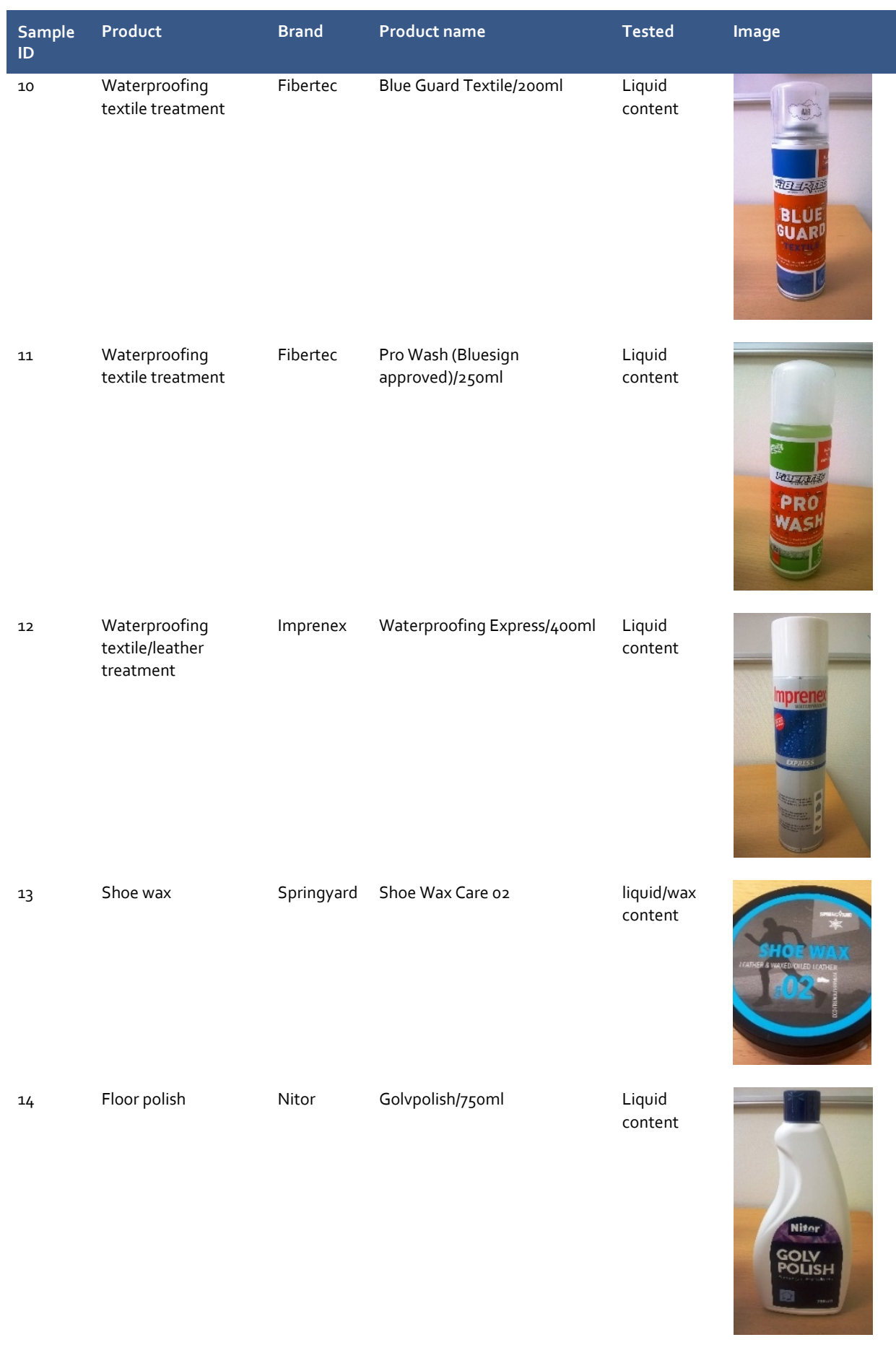




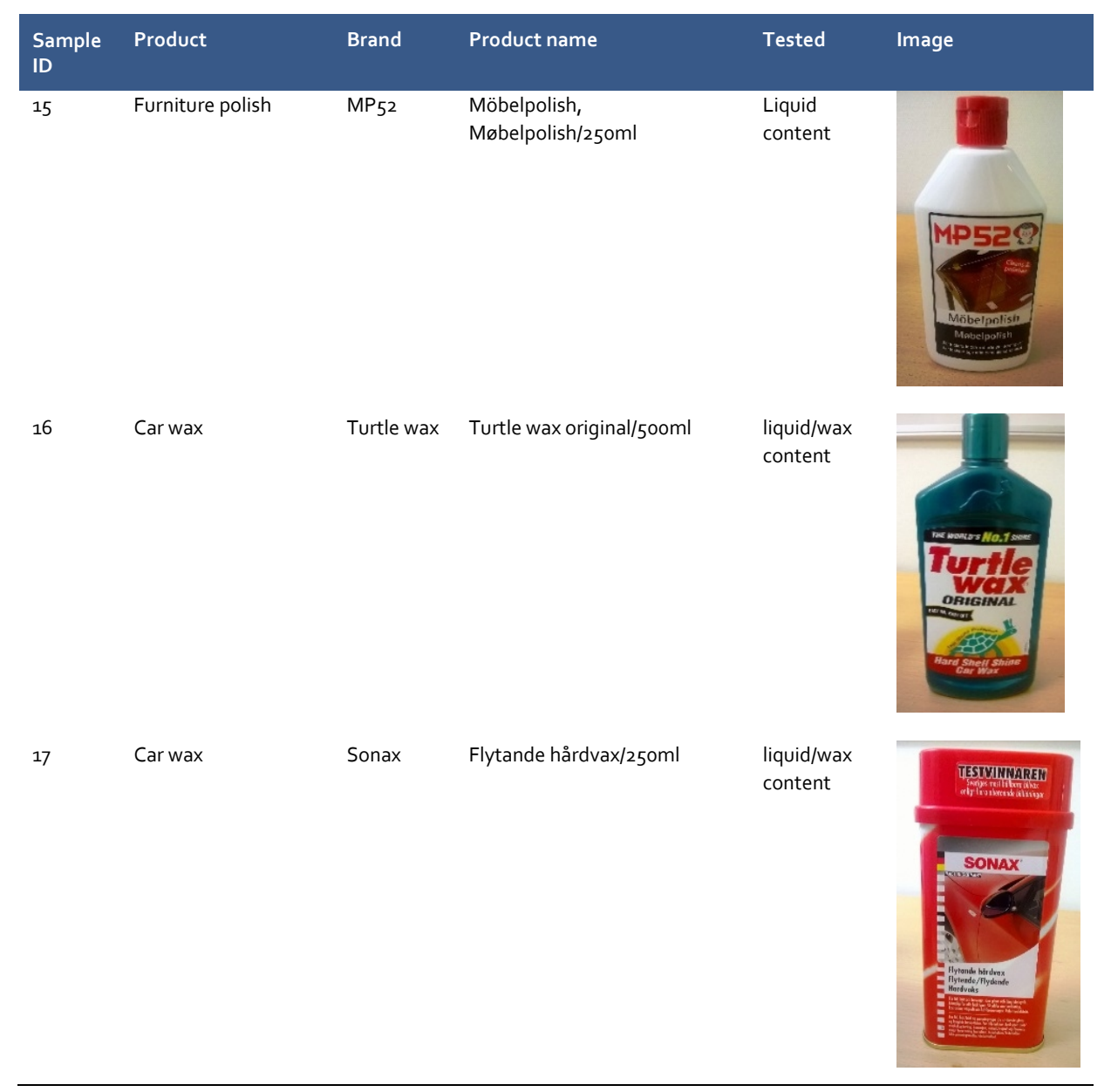




\section{Annex 3. Details of analysed products sampled in 2014}

Table 1: Products sampled in 2014

Sample Product / Type of product ID

1 Table cloth 1

2

Table cloth 2, Maud Teflonduk

\section{Product}
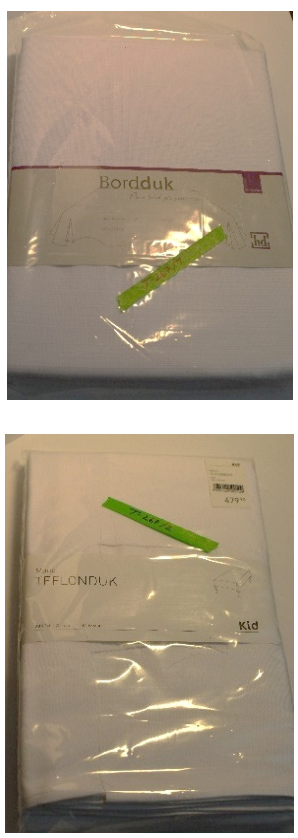

Baking paper 1, Unik

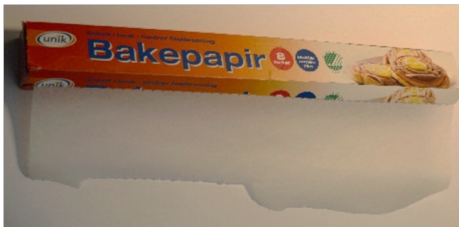

Baking paper 2, Toppits
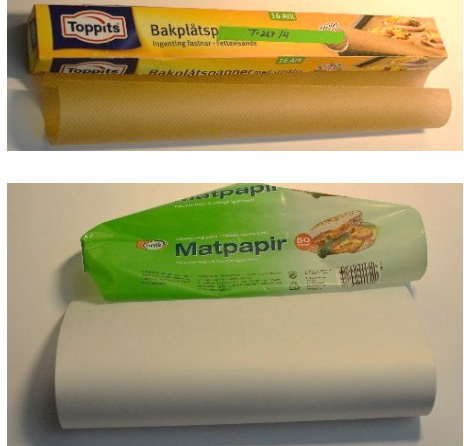


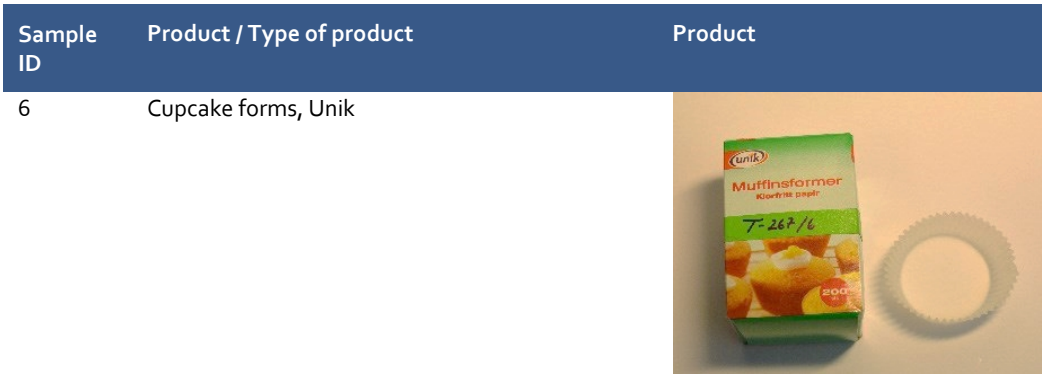
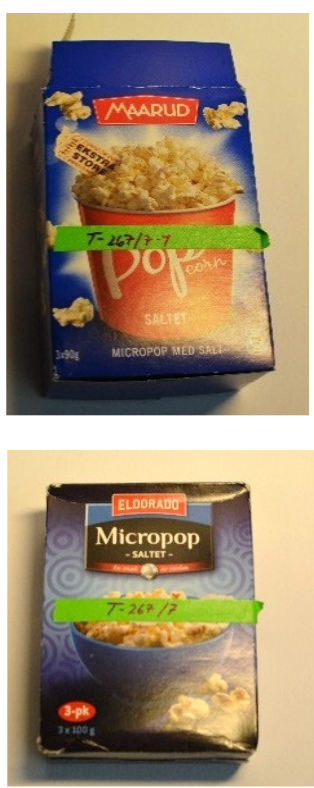

8

Car wax/polish 1 Turtle wax

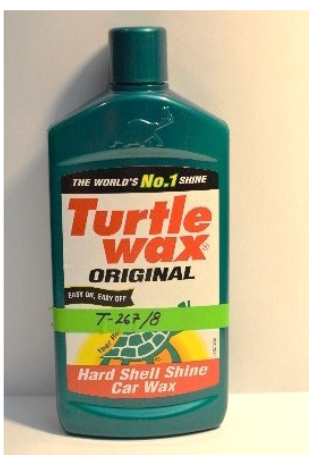

9

Car wax/polish 2 Autoglym

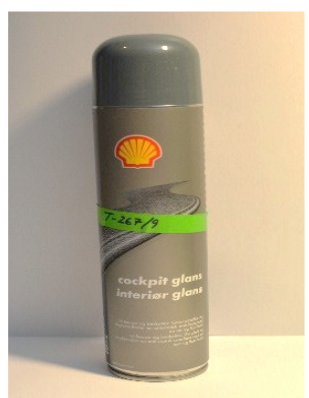




\begin{tabular}{l|l|l} 
Sample & Product / Type of product & Product \\
ID & &
\end{tabular}

Dishwasher liquid 1, Sun

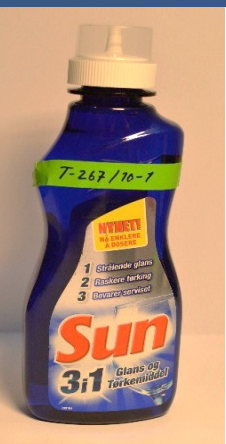

11

Dishwasher liquid 2, Finish

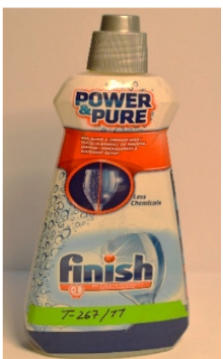

12

Waterproofing shoe treatment product 1 , Waterguard

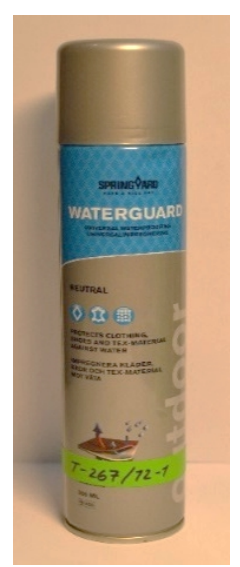

Waterproofing shoe treatment product 2, Kiwi

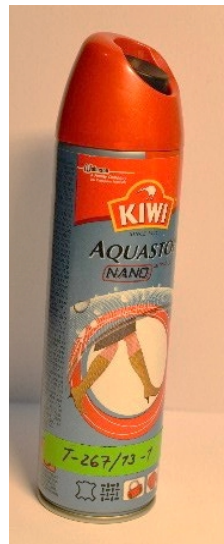




$\begin{aligned} & \text { Sample } \\ & \text { ID }\end{aligned}$
$\begin{array}{lll}\text { Product / Type of product } \\ \mathrm{B}\end{array}$
$\begin{aligned} & \text { Waterproofing textile treatment product 1, } \\ & \text { Nikwax two pack TX }\end{aligned}$

Waterproofing textile treatment product 2, textile proof, Toko

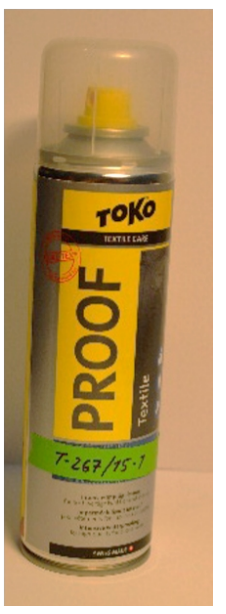

Glider for skis 1, Swix HF7 Violet

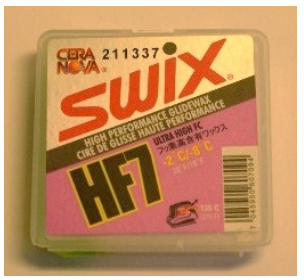

17

Ski wax, Swix VR 55 S+LV/Fiolett

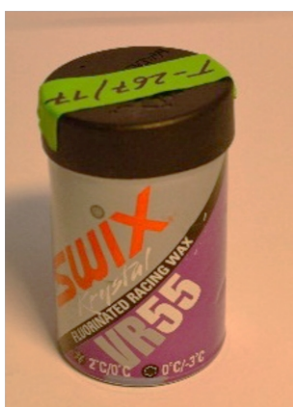




\begin{tabular}{l|l|l}
$\begin{array}{l}\text { Sample } \\
\text { ID }\end{array}$ & Product / Type of product & Product
\end{tabular}

18 Glider 1, Swix LF6 Blue

19 Lubricant for bicycles, TF2 Teflon greasetube

19 Lubricant for bicycles, TF2 Teflon greasetube
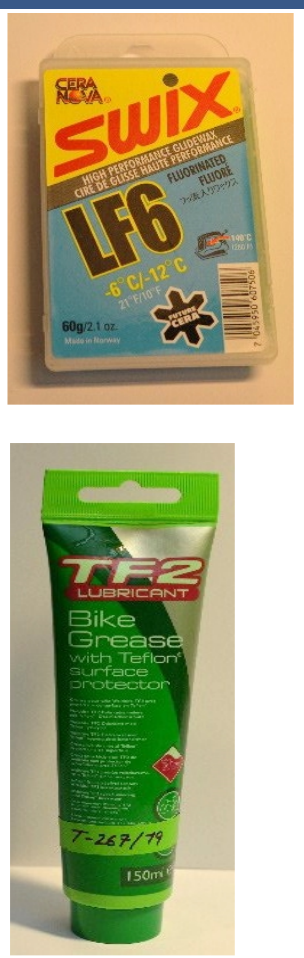

Dental floss 1, Jordan Easyslide

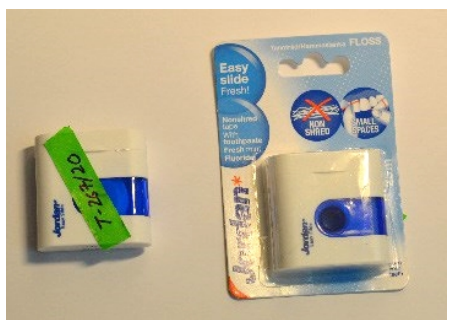

Dental floss 2, Colgate, mint

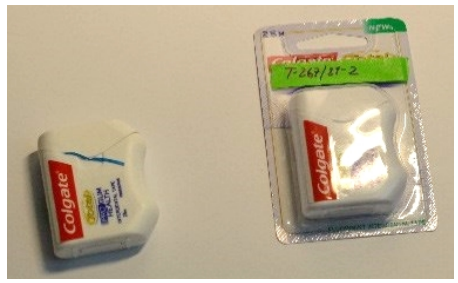

Non-stick baking ware, silicon 1, Invite

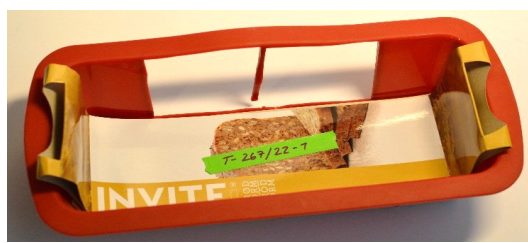




\begin{tabular}{|c|c|c|}
\hline $\begin{array}{l}\text { Sample } \\
\text { ID }\end{array}$ & Product / Type of product & Product \\
\hline 23 & Non-stick baking ware, Patisse ${ }^{1}$ & \\
\hline
\end{tabular}

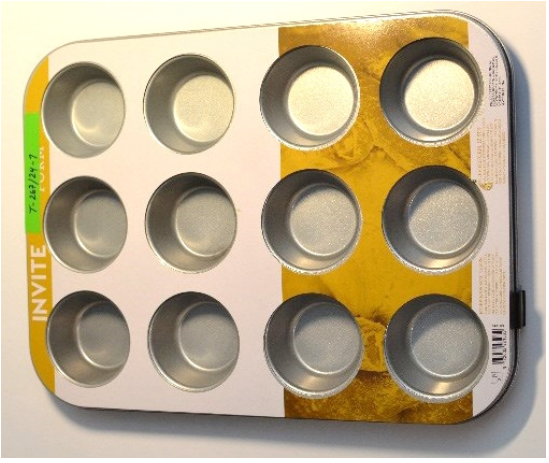

25 Non-stick baking ware, silicon, cupcakes 2, Patisse $^{2}$
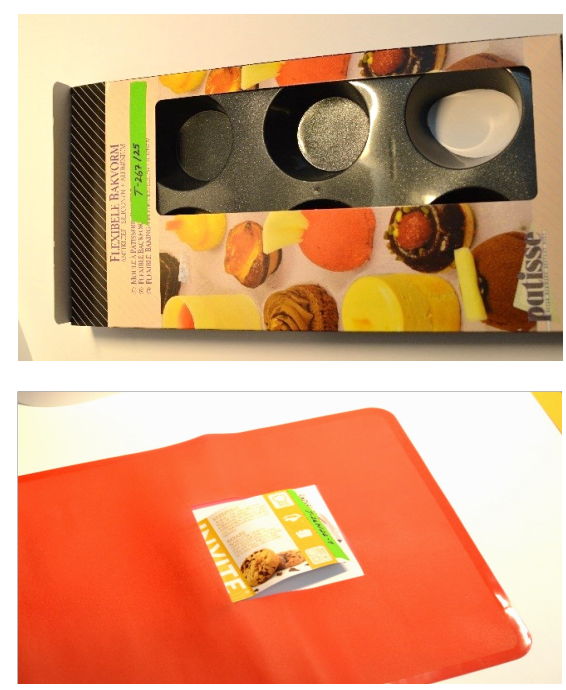

27 Reusable baking liner 2

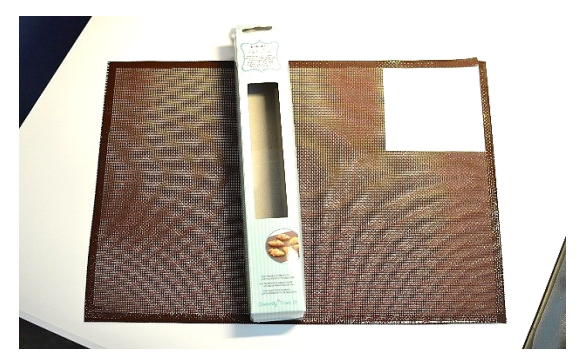

Note: $\quad{ }^{1}$ Referred to as Non-stick baking ware, silicon 2, Patisse, in Blom and Hanssen (2015).

${ }^{2}$ Referred to as Non-stick baking ware, cupcakes 2, Patisse, in Blom and Hanssen (2015).

Source: Blom and Hanssen, 2015. 


\section{Annex 4. Details of textiles samples in 2015}

Table 1: Textiles sampled in 2015

\begin{tabular}{|c|c|c|c|c|c|}
\hline $\begin{array}{l}\text { Sample } \\
\text { ID }\end{array}$ & Product & Brand & Product name & Tested & Image \\
\hline 124 & $\begin{array}{l}\text { Childrens } \\
\text { jacket }\end{array}$ & Galvin Green & $\begin{array}{l}\text { Richie Rainproof } \\
\text { jacket junior }\end{array}$ & $\begin{array}{l}\text { Outer material: } \\
\text { bluegreen textile }\end{array}$ & \\
\hline 125 & Jacket & Galvin Green & $\begin{array}{l}\text { Robin Windstopper } \\
\text { mintgrön }\end{array}$ & $\begin{array}{l}\text { Outer material: } \\
\text { bluegreen textile }\end{array}$ & \\
\hline 147 & Jacket & Five seasons & $\begin{array}{l}\text { Latitude jacket } \\
\text { marine }\end{array}$ & $\begin{array}{l}\text { Outer material: } \\
\text { blue textile }\end{array}$ & \\
\hline 150 & $\begin{array}{l}\text { Childrens } \\
\text { jacket }\end{array}$ & $\begin{array}{l}\text { Peak } \\
\text { Performance }\end{array}$ & $\begin{array}{l}\text { Down jacket, child } \\
\text { JRHELIUMJ }\end{array}$ & $\begin{array}{l}\text { Outer material: } \\
\text { blue textile }\end{array}$ & \\
\hline
\end{tabular}




\begin{tabular}{|c|c|c|c|c|c|}
\hline $\begin{array}{l}\text { Sample } \\
\text { ID }\end{array}$ & Product & Brand & Product name & Tested & Image \\
\hline 155 & $\begin{array}{l}\text { Childrens } \\
\text { shoe }\end{array}$ & DC & $\begin{array}{l}\text { DC Shoe Toddler } \\
\text { trace TX Fuchsia }\end{array}$ & $\begin{array}{l}\text { Outer material: } \\
\text { pink textile }\end{array}$ & \\
\hline 177 & Shoe & JOBI & $\begin{array}{l}\text { JOBI walkingsko } \\
\text { herr }\end{array}$ & $\begin{array}{l}\text { Outer material: } \\
\text { grey fabric } \\
\text { (textile) }\end{array}$ & \\
\hline 184 & $\begin{array}{l}\text { Childrens } \\
\text { jacket }\end{array}$ & Didriksson & Wylie Kid's Jacket & $\begin{array}{l}\text { Outer material: } \\
\text { blue textile }\end{array}$ & \\
\hline 185 & $\begin{array}{l}\text { Childrens rain } \\
\text { clothing }\end{array}$ & Didriksson & Makalu Kid's Set & $\begin{array}{l}\text { Outer material: } \\
\text { red textile }\end{array}$ & \\
\hline
\end{tabular}


Nordic Council of Ministers

Nordens Hus

Ved Stranden 18

DK-1061 Copenhagen K

www.norden.org

\section{ANALYSIS OF PFASs AND TOF IN PRODUCTS}

Per- and polyfluorinated substances (PFASs) are a large group of substances used in industrial and consumer applications. There are thousands of PFASs on the global market, for many of which there is little information on their use. This study is a follow-up of a NORAP project from 2015 where different household products were analysed for PFASs. Here we further analysed these products for total organic fluorine (TOF) together with new analyses for individual PFASs and TOF in product types that are known to or suspected to contain PFASs. The analyses of new products showed that PFASs are widely used. The comparisons between analysed individual PFASs and TOF concentrations showed that for most samples the detected individual PFAS constituted only a very minor part of the TOF, illustrating large data gaps in our knowledge on which PFASs that are being used in these products.

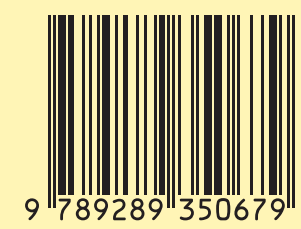

